\title{
Predicting Binding Affinities for GPCR Ligands Using Free-Energy Perturbation
}

\author{
Eelke B. Lenselink, ${ }^{\dagger}$ Julien Louvel, ${ }^{\dagger}$ Anna F. Forti, ${ }^{\dagger}$ Jacobus P. D. van Veldhoven, ${ }^{\dagger}$ Henk de Vries, ${ }^{\dagger}$
} Thea Mulder-Krieger, ${ }^{\dagger}$ Fiona M. McRobb, ${ }^{\ddagger}$ Ana Negri, ${ }^{\ddagger}$ Joseph Goose, ${ }^{\ddagger}$ Robert Abel, ${ }^{\ddagger}$ Herman W. T. van Vlijmen, ${ }^{\dagger}$ Lingle Wang, ${ }^{\ddagger}$ Edward Harder, ${ }^{\ddagger}$ Woody Sherman, ${ }^{\ddagger}$ Adriaan P. IJzerman, ${ }^{*}{ }^{\dagger}$ and Thijs Beuming*,

${ }^{\dagger}$ Division of Medicinal Chemistry, Leiden Academic Centre for Drug Research, Leiden University, Leiden 2300 RA, The Netherlands ${ }^{\ddagger}$ Schrödinger, Inc., 120 West 45th Street, New York, New York 10036, United States

Supporting Information

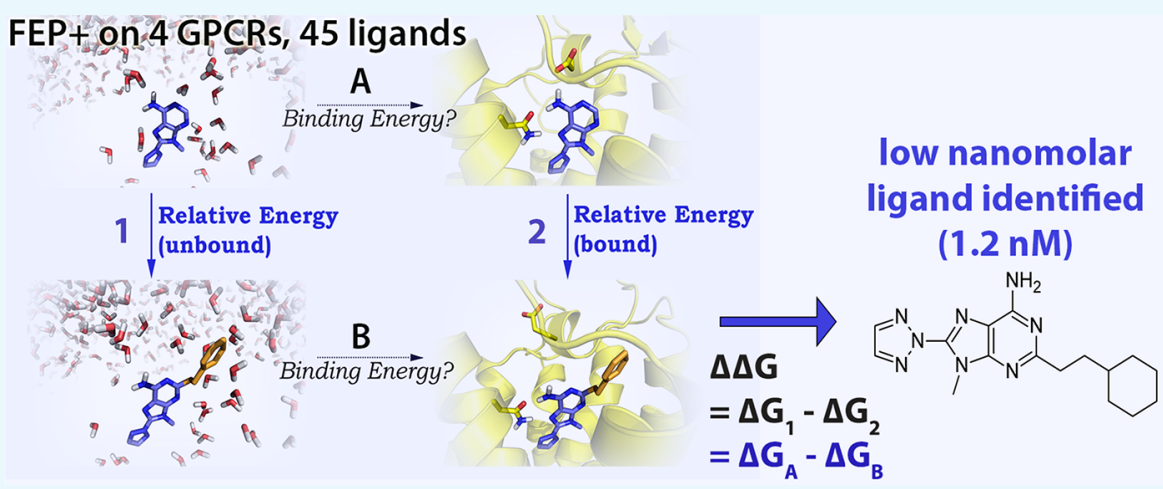

ABSTRACT: The rapid growth of structural information for G-protein-coupled receptors (GPCRs) has led to a greater understanding of their structure, function, selectivity, and ligand binding. Although novel ligands have been identified using methods such as virtual screening, computationally driven lead optimization has been possible only in isolated cases because of challenges associated with predicting binding free energies for related compounds. Here, we provide a systematic characterization of the performance of free-energy perturbation (FEP) calculations to predict relative binding free energies of congeneric ligands binding to GPCR targets using a consistent protocol and no adjustable parameters. Using the FEP+ package, first we validated the protocol, which includes a full lipid bilayer and explicit solvent, by predicting the binding affinity for a total of 45 different ligands across four different GPCRs (adenosine $\mathrm{A}_{2 \mathrm{~A}} \mathrm{AR}, \beta_{1}$ adrenergic, CXCR4 chemokine, and $\delta$ opioid receptors). Comparison with experimental binding affinity measurements revealed a highly predictive ranking correlation (average spearman $\rho=0.55$ ) and low root-mean-square error $(0.80 \mathrm{kcal} / \mathrm{mol})$. Next, we applied $\mathrm{FEP}+$ in a prospective project, where we predicted the affinity of novel, potent adenosine $A_{2 A}$ receptor $\left(A_{2 A} R\right)$ antagonists. Four novel compounds were synthesized and tested in a radioligand displacement assay, yielding affinity values in the nanomolar range. The affinity of two out of the four novel ligands (plus three previously reported compounds) was correctly predicted (within $1 \mathrm{kcal} / \mathrm{mol}$ ), including one compound with approximately a tenfold increase in affinity compared to the starting compound. Detailed analyses of the simulations underlying the predictions provided insights into the structural basis for the two cases where the affinity was overpredicted. Taken together, these results establish a protocol for systematically applying FEP+ to GPCRs and provide guidelines for identifying potent molecules in drug discovery lead optimization projects.

\section{INTRODUCTION}

Since the release of the first $G$ protein-coupled receptor (GPCR) crystal structure in 2000, ${ }^{1}$ research has shifted toward structure-based studies on these pharmaceutically relevant proteins. $^{2}$ Indeed, between 2014 and 2016 more than a dozen novel, unique crystal structures have been reported, including multiple class B and two class C GPCRs. ${ }^{3}$ These crystal structures facilitate the understanding of the structural basis of ligand binding, selectivity, and receptor function. ${ }^{4}$
Additionally, they function as starting points for structure-based computational studies including virtual screening. ${ }^{5}$

One of the major hurdles in drug discovery in terms of costs is lead optimization. ${ }^{6}$ Computer-aided drug design (CADD) provides valuable tools for hit and lead discovery; however, the added value of CADD techniques in terms of predicting

Received: June 20, 2016

Accepted: August 15, 2016

Published: August 30, 2016 


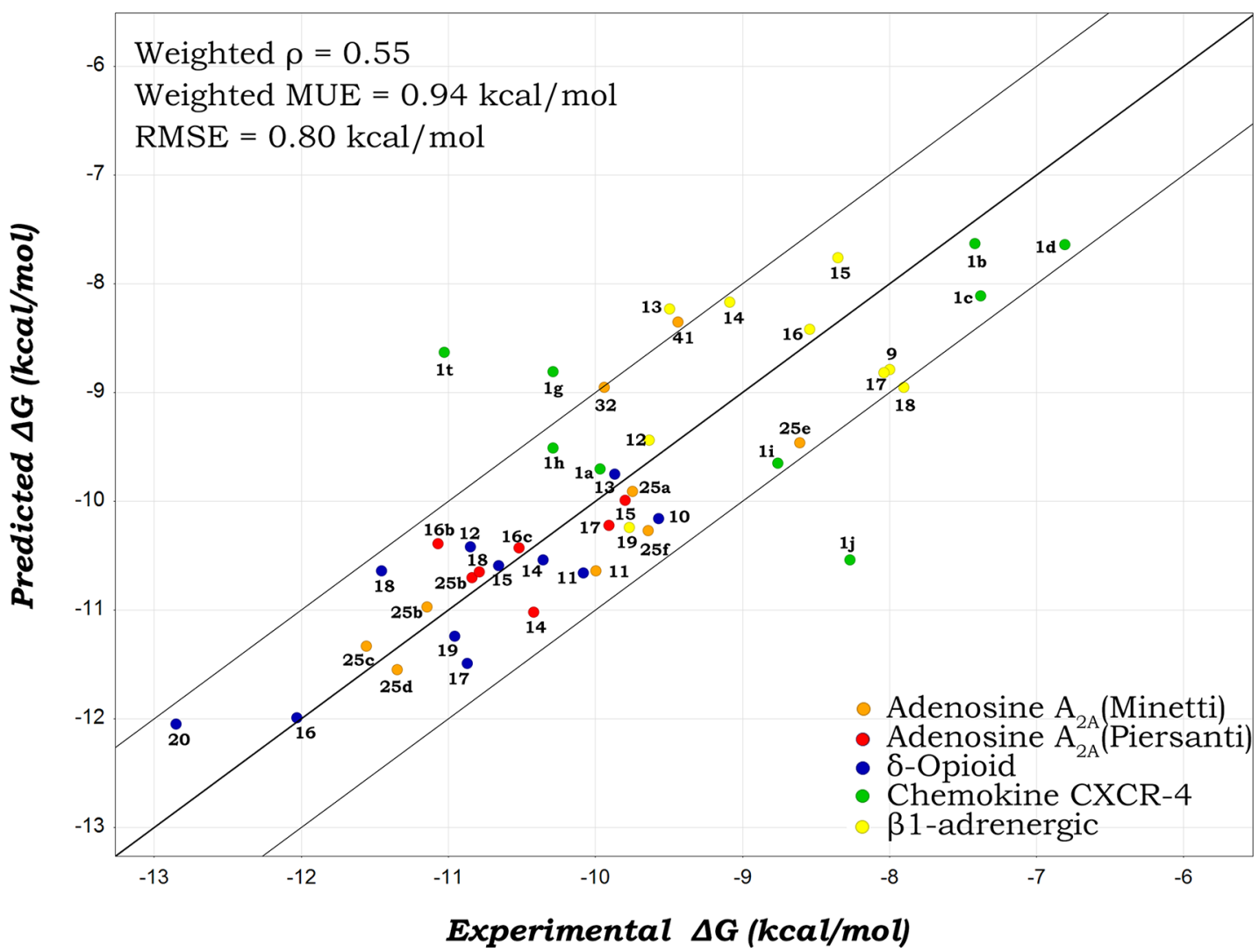

Figure 1. Predicted vs experimental $\Delta G$ for all 45 compounds. Compounds are labeled with their compound names and colored by receptor. The black line represents the line through the origin with a slope of 1 . The gray lines represent the $1 \mathrm{kcal} / \mathrm{mol}$ error line. The weighted average ranking correlation coefficient (weighted Spearman $\rho$ ) was calculated using the ranking correlation coefficient for every dataset individually and weighting by the dataset size. The root-mean-square deviation was calculated on the individual $\Delta G$ values. Finally, the average weighted MUE was calculated on the raw data $(\Delta \Delta G$ values $)$ and weighted by the number of perturbations for each dataset.

binding affinity in lead optimization has traditionally been modest. ${ }^{7}$ Virtual screening methods often perform well in terms of distinguishing weak and strong binders from inactive or decoy compounds but do not allow quantitative prediction of affinity for a congeneric series. ${ }^{8}$ On the other hand, more rigorous free-energy calculation methods like free-energy perturbation (FEP) and thermodynamic integration (TI) have the promise of accurately predicting the free energy of binding, but applications to drive discovery have been limited due to uncertainties about the accuracy of force fields, insufficient sampling, time-consuming setup, and significant computational demands. ${ }^{9}$ In addition, the application of rigorous free-energy methods to GPCRs is perhaps more challenging in many cases than soluble enzyme targets because of the lipid bilayer, buried waters, binding-site flexibility, and other complicating factors.

With the recent advances in improved force fields for proteins and small molecules ${ }^{10}$ together with the development of more efficient sampling strategies, such as replica exchange, orthogonal space tempering, and replica exchange with solute tempering (REST), ${ }^{11}$ accurate and reliable predictions of protein-ligand binding free energies have been achieved. ${ }^{9 a, 12}$ Furthermore, general-purpose graphics processing units (GPGPUs or GPUs) have significantly improved the performance and cost of running simulations compared to those in traditional central processing unit (CPU) clusters. Indeed, it is now possible to get more than 200 -fold speedup in running molecular dynamics simulations on a single GPU compared to a single CPU. The combination of improved force fields, enhanced sampling methods, and GPU computing has made FEP an attractive approach for lead optimizations in drug discovery projects. Prospective applications of FEP have been successful in a number of cases, such as predicting one of the most potent non-nucleoside reverse transcriptase inhibitors, ${ }^{13}$ including those that show activity toward mutant strains, ${ }^{14}$ inhibitors of the macrophage migration inhibitory factor, ${ }^{15}$ and drug-like inhibitors for IRAK4 and TYK2. ${ }^{\text {a }}$

In the past, several FEP studies have been conducted on GPCR homology models, usually to validate the model by making changes to the protein or to the ligand and predicting the effect. ${ }^{16}$ Additional studies have used crystal structures of GPCRs to study the influence of in silico mutagenesis on agonist- and antagonist-bound structures of $\mathrm{A}_{2 \mathrm{~A}} \mathrm{R},{ }^{17}$ to rationalize the difference in binding affinity for a fragment, ${ }^{18}$ or to explain the structure-activity relationship (SAR) on JDTic, a $\kappa$-opioid receptor (KOP) antagonist. ${ }^{19}$ However, a systematic validation of FEP calculations against multiple GPCRs with different ligand series has not yet been performed.

In this study, we have evaluated the performance of FEP+, ${ }^{9 a}$ a recently developed workflow for large-scale application of FEP, to a dataset of 45 ligands against four different class A GPCRs. Motivated by the promising retrospective performance, we also applied FEP+ in a prospective fashion. The affinity of 46 derivatives was predicted for the $A_{2 A} R$, and four novel compounds were synthesized, leading to the discovery of a compound with approximately tenfold increase in affinity. 
Table 1. Overview of the Results for Each Individual Dataset

\begin{tabular}{|c|c|c|c|c|c|c|c|}
\hline dataset/receptor & $\begin{array}{c}\text { no. of } \\
\text { ligands }\end{array}$ & $\underset{\text { range }}{\text { experimental }} \Delta G^{a}$ & $\begin{array}{c}\text { R FEP } \\
\text { observed }^{b}\end{array}$ & $\begin{array}{l}\text { R MM-GBSA } \\
\text { observed }^{b}\end{array}$ & $R$ expected ${ }^{c}$ & $\operatorname{MUE}(\min / \max )^{b}$ & $\begin{array}{l}\text { avg/max } \\
\text { hysteresis }\end{array}$ \\
\hline Minetti et al. $.^{25} /$ adenosine $\mathrm{A}_{2 \mathrm{~A}}$ & 9 & $-8.61 /-11.56$ & 0.78 & -0.31 & $0.68 \pm 0.17$ & $0.68(0.00 / 2.52)$ & $0.68 / 2.28$ \\
\hline Piersanti et al. ${ }^{22} /$ adenosine $A_{2 A}$ & 7 & $-9.80 /-11.07$ & 0.55 & 0.33 & $0.39 \pm 0.35$ & $0.58(0.05 / 1.44)$ & $0.53 / 1.15$ \\
\hline Thoma et al. ${ }^{23} /$ chemokine CXCR4 & 9 & $-6.81 * /-11.03$ & 0.45 & 0.11 & $0.81 \pm 0.11$ & $1.56(0.08 / 4.18)$ & $1.79 / 4.34$ \\
\hline Yuan et al. ${ }^{50} / \delta$-opioid & 11 & $-9.57 /-12.85$ & 0.85 & -0.25 & $0.71 \pm 0.14$ & $0.69(0.06 / 1.72)$ & $1.01 / 2.50$ \\
\hline Christopher et al. ${ }^{34} / \beta 1$-adrenergic & 9 & $-7.90 /-9.77$ & 0.39 & 0.64 & $0.50 \pm 0.27$ & $1.08(0.13 / 2.6)$ & $0.82 / 3.08$ \\
\hline weighted average $R$ & & & 0.62 & 0.01 & 0.62 & & \\
\hline
\end{tabular}

${ }^{a}$ The number of ligands and range of experimental affinities for the studied ligands ( $\mathrm{min} / \mathrm{max}$ ). For the Chemokine receptor CXCR4, the minimum affinity was set to $-6.81 \mathrm{kcal} / \mathrm{mol}$ (asterisk, see the text). ${ }^{b}$ As a validation metric, the correlation $(R)$ is given for both FEP and MM-GBSA. The MUE was calculated for FEP based on the $\Delta \Delta G$ data. ${ }^{c}$ The expected $R$ was calculated by assuming an RMSE of $1.1 \mathrm{kcal} / \mathrm{mol}$ in the calculations. ${ }^{20}$ The average correlation coefficient was weighted by the dataset size.

These results further validate the applicability of FEP+ for lead optimization across a wide range of target classes, including membrane-bound proteins.

\section{RESULTS AND DISCUSSION}

Overall Results. Our application of FEP+ relies on a previously published workflow ${ }^{9 a}$ adopted to accommodate membrane proteins such as GPCRs (see Experimental). Because we were particularly interested in the performance of this workflow on different class A GPCRs, we selected SAR series ranging from 9 to 11 compounds each for four different targets (Figures S1-S5, Supporting Information). Targets were selected on the basis of (a) the quality of the crystal structure and (b) the availability of a series of congeneric compounds similar to the crystal structure ligand. Whereas FEP+ performance for all targets studied was in line with what was observed for globular proteins reported in a previous publication, the results for the $\mathrm{A}_{2 \mathrm{~A}} \mathrm{R}$ were particularly promising. Before applying $\mathrm{FEP}+$ in a prospective fashion to the $A_{2 A} R$, we first performed additional validation using a secondary set of molecules for this target. The cumulative results shown in Figure 1 are based on a total of 90 perturbations among 45 compounds. Overall, the FEP+ method performance against these GPCR series is comparable with the studies on non-membrane-bound proteins. ${ }^{9 a}$ Indeed, 39 out of the 45 compounds were predicted within $1 \mathrm{kcal} / \mathrm{mol}$ error of the experimental affinity. This is also indicated by the low RMSE of the experimental versus predicted affinities ( 0.80 $\mathrm{kcal} / \mathrm{mol}$ ) and the high ranking correlation coefficient (Spearman $\rho$ ), which was calculated for every dataset individually and weighted by the number of compounds for the total average value that we report $(\rho=0.55)$. Similarly, the weighted mean unsigned error (MUE) was calculated on the basis of raw data and weighted for every dataset individually by the number of perturbations. The weighted $\rho$ of 0.55 (minimum: 0.2 , maximum: 0.83 ) and a weighted MUE of $0.94 \mathrm{kcal} / \mathrm{mol}$ (minimum: $0.58 \mathrm{kcal} / \mathrm{mol}$, maximum: $1.56 \mathrm{kcal} / \mathrm{mol}$ ) indicate significant predictive capabilities and high accuracy. The performance quality appeared to be target-dependent, with a range from satisfactory to excellent results for four out of five targets. The reasons for the system dependence are further discussed in the next section.

Results by Target. The results for each individual target are shown in Table 1 and Figures S1-S5, demonstrating significant target dependence (see Figures S6-S10). The MUE ranged from $0.58 \mathrm{kcal} / \mathrm{mol}\left(\mathrm{A}_{2 \mathrm{~A}} \mathrm{R}\right)$ to $1.56 \mathrm{kcal} / \mathrm{mol}(\mathrm{CXCR} 4)$ and the coefficient of determination $(R)$, from $0.39\left(\beta_{1}\right.$-adrenergic receptor, $\beta_{1} \mathrm{AR}$ ) to 0.85 ( $\delta$ opioid receptor, $\left.\mathrm{DOP}\right)$. The $R$-value, as a general rule, is highly dependent on dataset size and potency span, with smaller potency spans resulting in low correlations, even if predictions approached experimental accuracy/uncertainty. The dependence of this correlation on the dynamic range of the data has been covered in detail previously. $^{9 a, 20}$ Indeed, the low MUE indicates accurate performance of $\mathrm{FEP}+$ on these ligands/targets, but datasets with small experimental dynamic ranges of binding affinities can result in low $R$ values, even when the MUE is low. A more meaningful measure is to compare the observed $R$ with an expected $R$ resulting from assuming an expected prediction error of $1.1 \mathrm{kcal} / \mathrm{mol}$. For all cases, expect for the CXCR4, the observed correlation coefficient $(R)$ is comparable with the expected $R$ for the given range in experimental affinity. For the weighted average, we obtained the same values $(0.62)$ for the observed and expected $R$. Some datasets performed better than average; for the $\mathrm{A}_{2 \mathrm{~A}} \mathrm{R}$ and DOP receptor, the observed $R$ between the FEP-predicted binding free energies and experimental data was somewhat larger than expected. In addition, smaller dataset sizes result in more variability in the computed statistics, which could explain the cases where the $R$ value is better than expected.

To compare FEP+ with a less computationally expensive method, we also predicted affinity values using MM-GBSA. In this case, no significant correlations were found except for the $\beta 1$-adrenergic ligands ${ }^{49}$ (shown in Table 1 and Figures S6S10).

The calculations of multiple perturbations for each ligand, as determined using the FEP+ mapper algorithm, allow for the estimation of sampling errors in the calculation through cycle closure analysis. ${ }^{12}$ Problematic calculations can a priori be identified from high hysteresis values (Figures S1-S5, red arrows). For example, a number of cycles involving perturbation of 11 to 41 for the $A_{2 A} R$ were found to have a high hysteresis, ranging between 1.34 and $2.11 \mathrm{kcal} / \mathrm{mol}$. Indeed, this prediction had a high absolute error of $2.52 \mathrm{kcal} /$ mol. Consequently, when this perturbation was excluded from the results, an increase in performance was observed $(R=0.82$, MUE $=0.57 \mathrm{kcal} / \mathrm{mol}$ ). In the case of the $\mathrm{A}_{2 \mathrm{~A}} \mathrm{R}$, perturbations involving compounds 32 and 41 had larger errors than other perturbations. This was expected because compounds 32 and 41 have different cores than those of the other molecules and a much large perturbation is required to mutate between compounds 32 or 41 and other ligands. If compounds 32 and 41 were omitted from the analysis, the correlation $(R)$ increased from 0.78 to 0.96 and the MUE decreased from 0.68 to $0.57 \mathrm{kcal} / \mathrm{mol}$. The SAR of these compounds has been studied previously using WaterMap, ${ }^{21}$ and although the results 


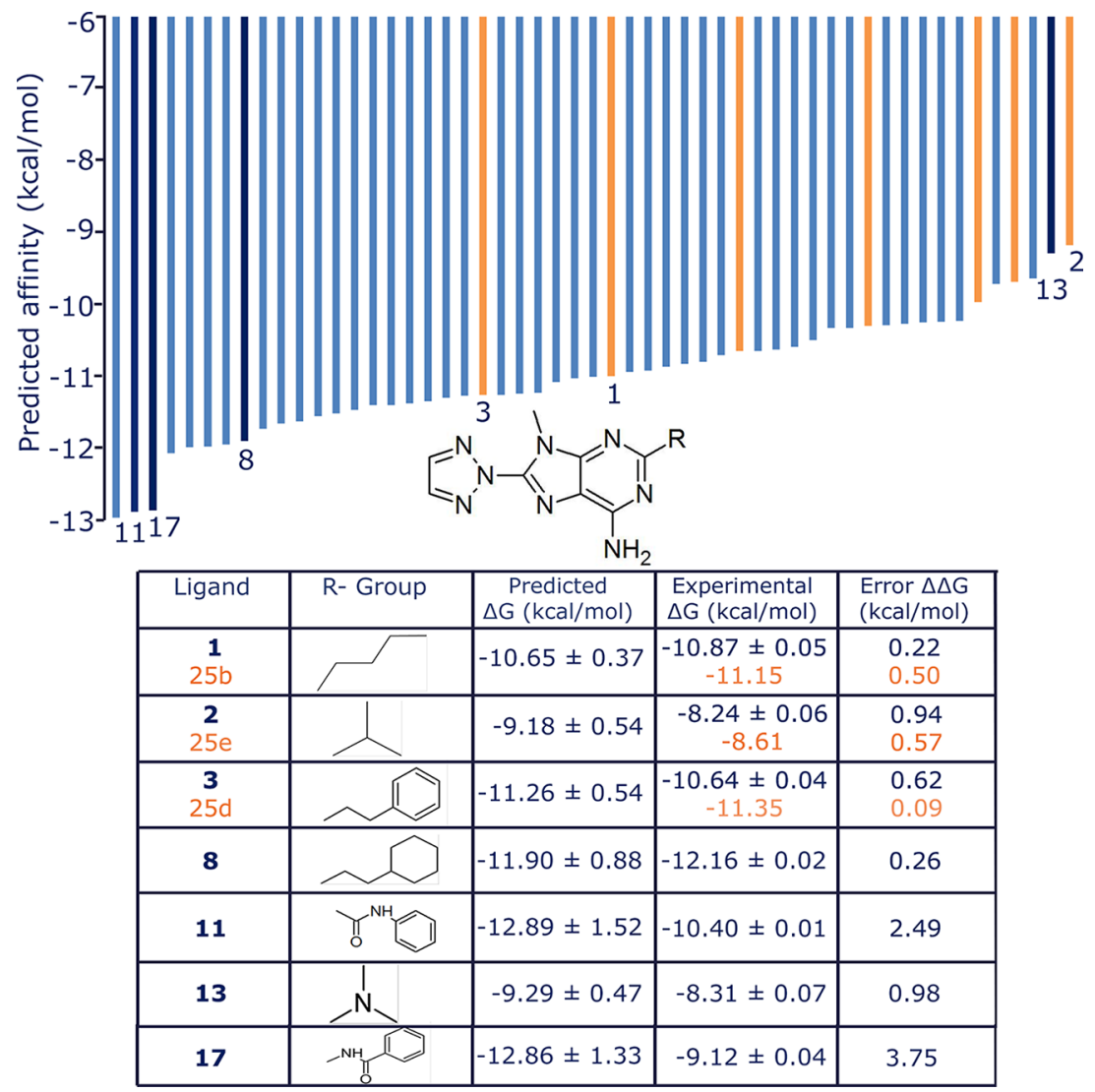

Figure 2. Predicted affinities for the 46 potential derivatives (Table S3) and 7 Minetti et al..$^{25}$ compounds using the 4EIY PDB structure for the FEP + simulations. Compounds highlighted in orange are Minetti et al. compounds, and compounds in dark blue represent the newly synthesized derivatives (top half of figure). The numbered compounds are all compounds that were synthesized, including the three compounds that have been described previously $(3 / 25 \mathrm{~d}, 1 / 25 \mathrm{~b}$, and $2 / 25 \mathrm{e})$. The predicted and experimental $\Delta G$ are given; previously determined experimental $\Delta G$ 's are highlighted in orange. The error shows the difference in predicted vs experimental $\Delta G$.

obtained in that study were also predictive, they required an ad hoc correction to ligand entropy for best performance.

Next, we validated the performance on a second, related dataset $^{22}$ for the $\mathrm{A}_{2 \mathrm{~A}} \mathrm{R}$, to further assess if FEP+ can be prospectively applied to this target. The correlation for the isolated dataset was not high, which was expected given that the affinities span less than 1 order of magnitude ( $K_{\mathrm{i}}$ range: 7.5-64 $\mathrm{nM}$ ). The MUE was in the same range for both datasets (MUE between 0.58 and 0.68 ). These results demonstrate that FEP+ can be applied successfully on two different datasets and, by extension, possibly on novel derivatives of the $A_{2 A} R$.

For the DOP receptor, the performance was comparable with the results we obtained for the $A_{2 A} R$. In fact, the observed $R$ was 1 standard deviation higher than the expected $R$. For both the $A_{2 A} R$ and DOP receptor, an exceptionally high resolution crystal structure was used $(1.8 \AA)$ with most water molecules resolved in both binding pockets, which may partially explain why FEP+ performed so well on these targets.

For the CXCR4, the performance was below the expected $R$ and the MUE was also relatively high $(R, 0.45$; MUE, $1.56 \mathrm{kcal} /$ $\mathrm{mol})$. A few aspects of this dataset should be taken into account (Figure S5). First, most of the perturbations involved modifications at two or even three positions of the ligand and were relatively large in size compared to those of the other series and what has been previously attempted. ${ }^{9 a}$ Moreover, the experimental affinity of compound $1 \mathrm{~d}$ was set to $10000 \mathrm{nM}$ $(\Delta G=-6.81 \mathrm{kcal} / \mathrm{mol})$, whereas the true affinity was reported to be over $10000 \mathrm{nM}^{23}$ Finally, it should be noted that these thiourea compounds can adopt different tautomeric states, and in this FEP+ map, only one tautomer was considered. Despite these relatively high errors, it was still encouraging to see that FEP+ was able to predict several large perturbations, like $1 \mathrm{~d}$ to 1c (isopropyl to cyclopentyl) and $1 \mathrm{~g}$ to $1 \mathrm{t}$ (cycloheptyl to cyclohexyl), correctly (Figure S5).

Because of the relatively poor resolution of the $\beta_{1} \mathrm{AR}$ crystal structure $(>2.5 \AA)$, which resulted in a structure with no buried binding-site waters, we included water molecules from a WaterMap simulation (see Experimental). WaterMap has recently been shown to be a useful tool for placing waters in structures for which the resolution is relatively low. ${ }^{24}$ Comparisons with experimental results revealed a relatively high MUE compared to that of the $\mathrm{A}_{2 \mathrm{~A}} \mathrm{R}$ and DOP receptor; however, the observed MUE still falls within the range of previously reported errors for this method. ${ }^{9 a}$

At the time of writing, an updated version of OPLS force field was released (OPLS3). ${ }^{106}$ Therefore, we repeated the same perturbations using OPLS3 (Table S2). In most cases, the MUE was in line with the results obtained with OPLS2.1, with a slightly higher MUE value for OPLS3 in three of the four cases. On the other hand, hysteresis values were lower for OPLS3, possibly due to the improved protein parameters. ${ }^{10 \mathrm{~b}}$ Therefore, we used the OPLS3 force field to determine the origin of the overpredicted compounds (see section "Overprediction of compounds 11 and 17”).

Prospective Results: Computational Setup. We further validated the performance of $\mathrm{FEP}+$ prospectively, by predicting 
Scheme 1. Previously Described and Synthesized Compounds, ${ }^{25}$ from Left to Right, 1 (25b), 2 (25e), and 3 (25d)<smiles></smiles>

\section{Scheme 2. Newly Synthesized Compounds 8 and 11}<smiles></smiles>

${ }^{a}$ Reagents and conditions: (a) cyclohexylacetylene, $\mathrm{Pd}\left(\mathrm{PPh}_{3}\right)_{2} \mathrm{Cl}_{2}, \mathrm{CuI}, \mathrm{NEt}_{3}$, dioxane, rt, $1 \mathrm{~h}$; (b) aq $\mathrm{NH}_{3}$, dioxane, $70{ }^{\circ} \mathrm{C}, 15 \mathrm{~h} ;(\mathrm{c}) \mathrm{H}_{2}, \mathrm{Pd} / \mathrm{C}$, EtOH, rt, 60 h, 44\% (3 steps); (d) $\mathrm{Br}_{2}$, acetate buffer $\mathrm{pH}=4 / \mathrm{MeOH} / \mathrm{THF}, 15{ }^{\circ} \mathrm{C}$ to rt, $20 \mathrm{~min}$; (e) $1,2,3$-triazole, $\mathrm{Cs}_{2} \mathrm{CO}_{3}$, dimethylformamide (DMF), $90{ }^{\circ} \mathrm{C}, 15 \mathrm{~h}, 4.5 \%$ for 8 (2 steps); (f) aq $\mathrm{NH}_{3}, \mathrm{CH}_{3} \mathrm{CN}, 55^{\circ} \mathrm{C}, 98 \%$; (g) Br $\mathrm{Br}_{2} \mathrm{DMF} / \mathrm{CCl}_{4} 1 / 2$, rt, $15 \mathrm{~h}$; and (h) $\mathrm{Mo}(\mathrm{CO}){ }_{6}, \mathrm{Et}_{4} \mathrm{NCl}$, aniline, dioxane, $130{ }^{\circ} \mathrm{C}, 4 \mathrm{~h}, 2.3 \%$ (3 steps).

Scheme 3. Newly Synthesized Compounds 13 and 17
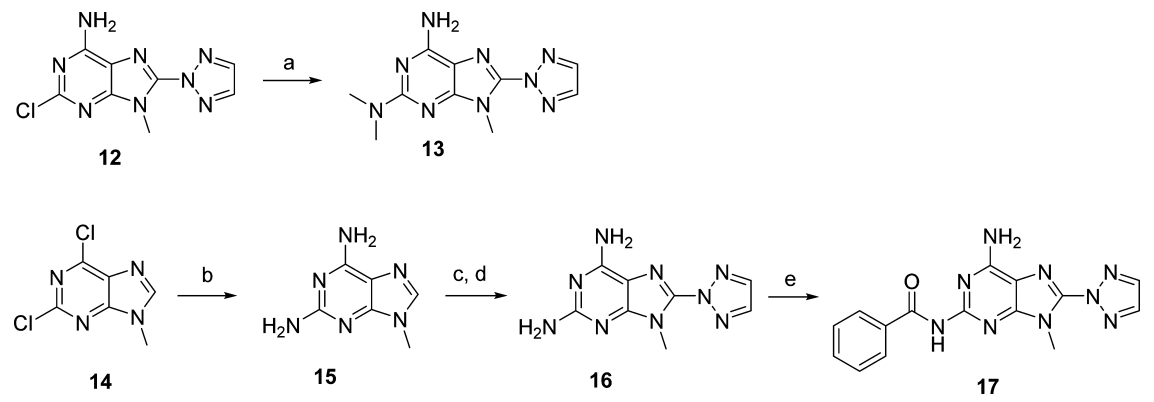

${ }^{a}$ Reagents and conditions: (a) $\mathrm{Me}_{2} \mathrm{NH}, \mathrm{H}_{2} \mathrm{O}, 120^{\circ} \mathrm{C}, 26 \%$; (b) $\mathrm{NH}_{3}$, EtOH, $160{ }^{\circ} \mathrm{C}, 24 \mathrm{~h}, 31 \%$; (c) $\mathrm{Br}_{2}, \mathrm{DMF} / \mathrm{CCl}_{4}$ 1/2, rt, 15 h; (d) 1,2,3-triazole, $\mathrm{Cs}_{2} \mathrm{CO}_{3}, \mathrm{DMF}, 120^{\circ} \mathrm{C}, 5 \mathrm{~h}, 82 \%$ (2 steps); and (e) BzCl, pyridine, rt, $30 \mathrm{~min}, 21 \%$.

the affinity of 46 potential new derivatives of the Minetti et al. compounds $^{25}$ (Table S3). These compounds were designed to cover a wide range of synthetically accessible substitutions. Affinities were predicted by perturbing two reference compounds into each derivative. These results were then merged with the retrospective map for the Minetti et al. dataset. We excluded compounds 32 and 41 from these results because of a different core of the molecule (see section Results by Target). Approximately 12 perturbations per week were completed on four Nvidia-780GTX graphic cards. Therefore, these prospective calculations can typically be completed within 1 week using 32 GPUs. This throughput is slightly lower than that in the previous study, which is a consequence of the system being slightly larger compared to the globular proteins studied previously, because of the presence of a membrane around the GPCR. Recently, a new version of Desmond has been released (version 4.4$)^{26}$ that has a 2 -fold speedup on GPUs compared to that in the version used here, making these calculations even more accessible for prospective application to live projects.

Experimental Results. On the basis of the FEP+ calculations of the $46 \mathrm{~A}_{2 \mathrm{~A}} \mathrm{R}$ derivatives, four novel derivatives were selected for synthesis. Three of these were predicted to have high affinity, and one, compound 13 (VC-28), served as a negative control. We further checked the predicted affinities of these four test cases by perturbing them into all experimentally tested reference compounds from Minetti et al. (Figure 2; 
Table S3). In addition to these novel compounds, we resynthesized three reference compounds tested before by Minetti et al. (1-3) to ensure that the affinities were comparable between labs (Figure 2). ${ }^{25}$

The four new compounds were synthesized from previously described purine derivatives. Namely, 6-chloro-2-iodo-9-methyl-9H-purine (4) was reacted with cyclohexylacetylene in a Sonogashira coupling to afford 2-alkynylated derivative 5, which in turn was treated with ammonia to yield adenine (6). Hydrogenation of the alkyne afforded alkyl derivative 7, which was then brominated and immediately reacted with 1,2,3triazole to yield compound $\mathbf{8}$. Alternatively, $\mathbf{4}$ was aminated at the 6-position to afford iodoadenine (9), which was then brominated and reacted with 1,2,3-triazole to yield iodo derivative 10. 10 was then reacted into a molybdenumcatalyzed aminocarbonylation reaction with aniline, with the catalyst $\mathrm{Mo}(\mathrm{CO})_{6}$ also serving as a source of $\mathrm{CO}$; this afforded benzamide derivative 11 (Schemes 1-3). 12 was reacted with dimethylamine to afford compound 13. Finally, dichloropurine 14 was diaminated, and the resulting compound 15 was submitted to the bromination/triazole coupling sequence, the product of which was reacted with benzoyl chloride to afford the 2-mono-acylated derivative 17 . The synthesized compounds were further tested for affinity in a radioligand binding assay for the $A_{2 A} R$. (Figures S11 and S12).

The differences between the experimental values obtained here (Figure 2, blue) and in the previous study ${ }^{25}$ (Figure 2, orange) were $0.45 \mathrm{kcal} / \mathrm{mol}$ on average. The largest difference was found for 3 with a difference of $0.71 \mathrm{kcal} / \mathrm{mol}$ between two experimental values, which is comparatively high but falls within the heterogeneous experimental uncertainty. ${ }^{27}$ These control compounds indicated that we were able to reproduce the affinities found by Minetti et al. ${ }^{25}$ The negative control was also in line with the experimental result, with significantly reduced affinity compared to that of the potent Minetti et al. compounds.

Compound 8, which was predicted to be significantly more potent than 1 , was in fact the most potent derivative $\left(K_{\mathrm{i}}=1.2\right.$ $\mathrm{nM}$ ) of all of the compounds tested here. The affinity was improved by approximately 10 -fold over the most potent compound in the Minetti series, which was compound 1 with an affinity of $10.7 \mathrm{nM}(-10.87 \mathrm{kcal} / \mathrm{mol})$. However, the predicted values for the benzamide, compound 17 , and the inverted benzamide, compound 11, deviated from what was found experimentally. Compound $\mathbf{1 7}$ in particular was overpredicted by $3.75 \mathrm{kcal} / \mathrm{mol}$, which is significantly higher than the largest error observed in the retrospective data (2.11 $\mathrm{kcal} / \mathrm{mol}$ for the perturbation of 11 to 41 ).

Overpredictions of Compounds 11 and 17. The overprediction of the affinity of compounds 11 and 17 urged us to further analyze simulations involving these compounds. Although large errors can occur occasionally, they are quite rare, happening only in about $3.3 \%$ of the perturbations for the previously reported dataset. ${ }^{9 a}$ This overprediction could be due to several reasons, such as (1) unconverged binding site hydration patterns, (2) multiple compound binding modes, (3) large inaccuracies in the force field, ${ }^{\mathrm{d}}$ or (4) incorrect system setup. On the basis of further analysis of the complex (bound) FEP+ simulations, we observed that the amide of compound $\mathbf{1 7}$ was able to form an interaction with Glu169 $9^{\mathrm{EL} 2}$ mediated through different water molecules (Figure 3). This interaction was stabilized by His $264^{7.29}$, which was treated as a protonated species as predicted by the PROPKA algorithm ${ }^{28}$ in the Protein

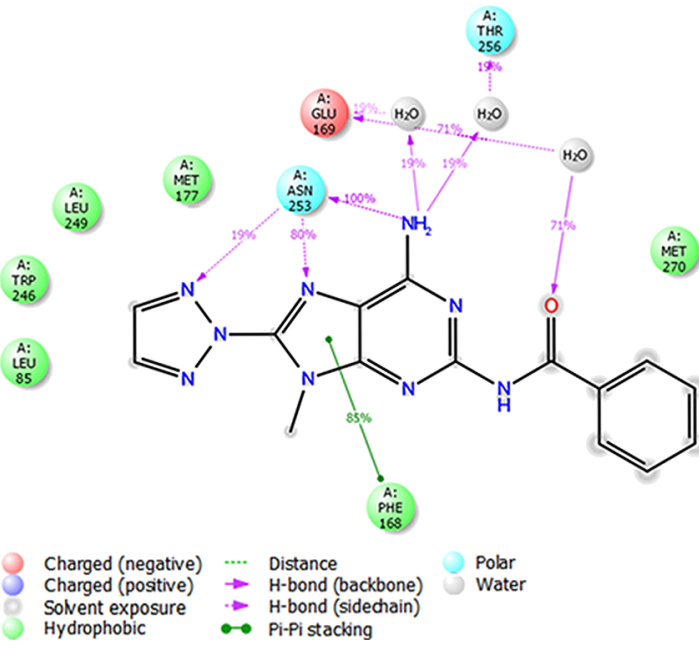

Figure 3. $2 \mathrm{D}$ representation of FEP+ simulation of replica 11 for ligand 17 , showing the percentage of time that an interaction is present during the $5 \mathrm{~ns}$ simulation. One of the most prominent interactions of the amide is the interaction with a bridging water that interacts with Glu169 ${ }^{\mathrm{EL} 2}$ and the oxygen of the amide.

Preparation Wizard (Figure 4). ${ }^{29}$ To further test the influence of the ionizable residues and the impact of these residues on the

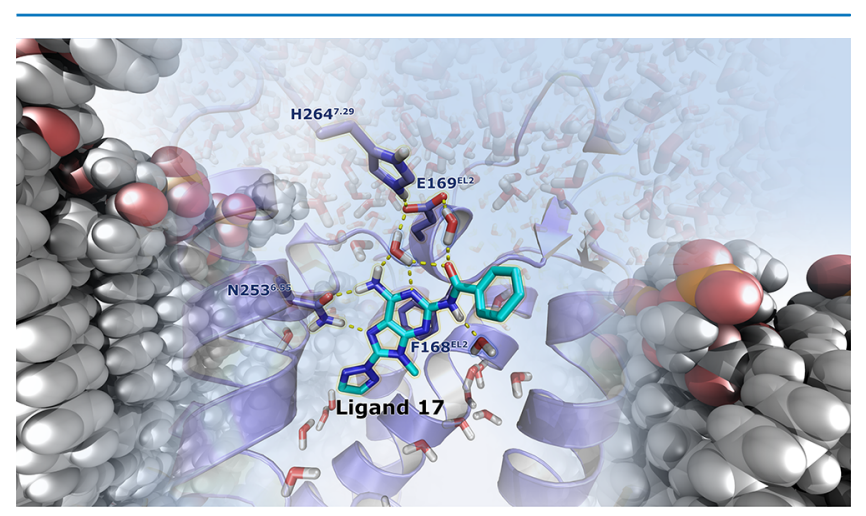

Figure 4. Representative snapshot of replica 11 for ligand 17, at 3.36 ns. The interactions that are predicted to be beneficial among the receptor, the amide, the core of the molecule, and different water molecules are shown. Two water molecules form bridging interactions with the residue Glu169 ${ }^{\mathrm{EL} 2}$. Moreover, the protonated His $264^{7.29}$ stabilizes this interaction by forming an additional interaction with Glu169 ${ }^{\mathrm{EL} 2}$. For clarity, transmembrane (TM) helix 7 is partially hidden (residues 265-275). The membrane lipids (POPC) are shown as spheres.

predicted affinities, we selected another crystal structure of the $\mathrm{A}_{2 \mathrm{~A}} \mathrm{R}$ that was co-crystallized with the same ligand (ZM241385, PDB: $3 \mathrm{PWH})^{30}$ but solved at a higher $\mathrm{pH}(\mathrm{pH}=8-8.75$, instead of $\mathrm{pH}=5$ for 4EIY). When we compared the 4EIY with $3 \mathrm{PWH}$ structure, we found that for $3 \mathrm{PWH}$ extracellular loop (EL) 3 is further away from EL2 with His264 $4^{7.29}$ oriented away from Glu169 ${ }^{\mathrm{EL} 2}$ (Figure S13). Because of this structural difference, His $264^{7.29}$ was predicted to be deprotonated (HIE) in the $3 \mathrm{PWH}$ structure, in line with both the $\mathrm{pH}$ $(\sim 8)$ and $\mathrm{p} K_{\mathrm{a}}$ of the histidine $\left(\mathrm{p} K_{\mathrm{a}}=6-6.5\right)$. His $264^{7.29}$ has been shown to be a residue that is involved in the dissociation of ZM241385. ${ }^{31}$ On the basis of this observation, we hypothesized that the misassignment of the protonation state of His $264^{7.29}$ and the conformation of EL3 were responsible for 


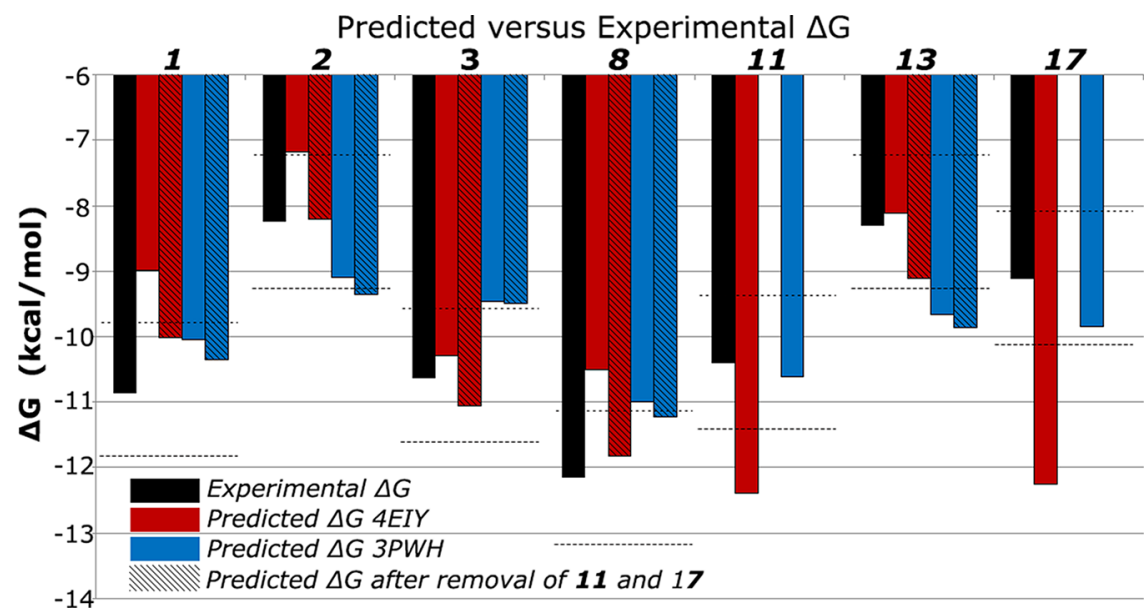

Figure 5. Predicted vs experimental $\Delta G$ for the seven ligands based on either the crystal structure 3PWH or 4EIY. On the basis of the difference between $4 \mathrm{EIY}$ and $3 \mathrm{PWH}$ predictions, we removed ligand 17 and then ligand $\mathbf{1 1}$. The red colored bars are predictions based on 4EIY, and the blue bars are predictions based on $3 \mathrm{PWH}$. The dashed bars represent predictions for both crystal structures after removal of ligands 11 and 17. For instance, for ligand 4, the predicted $\Delta G$ based on all ligands is $-10.51 \mathrm{kcal} / \mathrm{mol}$, whereas the experimental $\Delta G$ is $-12.16 \mathrm{kcal} / \mathrm{mol}$. After removal of ligands 11 and 17, the predicted $\Delta G$ is $-11.82 \mathrm{kcal} / \mathrm{mol}$. Dashed lines represent a $1 \mathrm{kcal} / \mathrm{mol}$ error line.

the overprediction of compounds 11 and 17. They both contain an amide that could interact more favorably with the protonated form of His but would require an energetic cost to be paid to protonate this His under the $\mathrm{pH}$ conditions in the experimental assays.

To enable a direct comparison between the two structures, two FEP+ maps were generated for both crystal structures based on the seven compounds that were synthesized in this work (Figures 2, S14, and S15). The predicted affinities for both are shown in Figure 5 (raw data in Table S4). The predictions based on the $3 \mathrm{PWH}$ crystal structure correlated better with the experimental results $(\mathrm{R} 3 \mathrm{PWH}=0.76$, 4EIY = 0.44 ; MUE $3 \mathrm{PWH}=1.24 \mathrm{kcal} / \mathrm{mol}, 4 \mathrm{EIY}=2.33 \mathrm{kcal} / \mathrm{mol}$ ).

This suggests an alternative mechanism for identifying erroneous predictions a priori based only on the predicted affinities. If we compare the differences between the predicted affinities (Figure 5 and $\Delta \Delta G 4 \mathrm{EIY}-3 \mathrm{PWH}$, Table S4), it is clear that the difference on average is high $(1.44 \mathrm{kcal} / \mathrm{mol})$, resulting mostly from differences for compounds 11 and 17 . In a prospective setting, when the experimental affinity is unknown, a second model could be of use; predictions where two models predict significantly different results should be deprioritized. For example, removing compounds 11 and 17 from both maps dramatically reduced the average difference between the values in the two maps (from 1.44 to $0.87 \mathrm{kcal} / \mathrm{mol}$ ), and there was a high correlation between the 4EIY- and 3PWH-based results $(R$ $=0.82$ between $4 \mathrm{EIY}$ and $3 \mathrm{PWH}$ ), with 4EIY performing the best for the five remaining compounds $\left(R^{2} 4 \mathrm{EIY}=0.96,3 \mathrm{PWH}\right.$ $=0.87$ ). Although we were able to test this method only retrospectively and on a small dataset, these results indicate that there is an added value of validating predicted affinities using a second model or crystal structure.

\section{CONCLUSIONS}

This study shows the value that free-energy calculations (specifically, FEP+) can have in GPCR drug discovery projects through the accurate prediction of relative binding free energies for congeneric compounds. The performance of free-energy methods had thus far only been studied anecdotally for GPCRs; here we studied it on four different targets involving different types of perturbations. Although the retrospective results indicated that the results are target-dependent, the results were still predictive and accurate for most targets, especially for the Adenosine $\mathrm{A}_{2 \mathrm{~A}}$ and $\mathrm{DOP}$ receptors. Moreover, even for some relatively large perturbations, good results were obtained, demonstrating the robustness of this approach. These results were in line with those that were previously obtained for globular proteins. Because these calculations can be performed within in a matter of days, the real strength of the approach is the accurate ranking of compounds for synthesis. On the basis of FEP+ calculations, we predicted and identified a highly potent antagonist (compound $8, K_{\mathrm{i}}=1.2 \mathrm{nM}$ ) and achieved a 10 -fold increase in potency by synthesizing only four compounds. Several predictions were incorrect, including both compounds 11 and 17, where we overpredicted the affinity. In that case, the cause of the erroneous predictions was retrospectively identified by using a different crystal structure. With the increase in the availability of crystal structures for GPCRs, we expect that FEP+ will be applied in a more systematic fashion, not only limited to predicting affinities of ligands but also possibly to the prediction of selectivity of ligands.

\section{EXPERIMENTAL SECTION}

Computational Setup. All calculations were performed using tools available in the Schrodinger Suite. ${ }^{32}$ Structures were retrieved from the $\mathrm{PDB}^{33}$ and subsequently prepared using the Protein Preparation Wizard. ${ }^{29}$ Protonation states were assigned using PROPKA. ${ }^{28}$ For the $\mathrm{A}_{2 \mathrm{~A}} \mathrm{R}$ (PDB: 4EIY) and the DOP receptor (PDB: $4 \mathrm{~N} 6 \mathrm{H}$ ), the $\mathrm{BRIL}$ insertion was replaced by the wild-type amino acids. For 4EIY, the first few amino acids of the crystal structure were mutated back to the original sequence, to improve the stability of TM1 (GAPP to MP). For the CXCR4 receptor (PDB: 3ODU), the T4 lysozyme was replaced by intracellular loop 3. For the $\beta_{1} \mathrm{AR}$ (PDB: 3ZPQ), the crystal structure of piperazine-based fragment " 19 " was used. $^{34}$ The crystal structure used here is a turkey $\beta_{1} \mathrm{AR}$, whereas the assay data is for the human receptor. However, as human and turkey binding sites are $100 \%$ identical, the results should be comparable. ${ }^{34}$ The model based on the crystal structure of $3 \mathrm{PWH}^{30}$ was generated in the following way: residues that were missing (e.g., EL2 149-158) were modeled 
using 4EIY, and we included the water molecules and the sodium ion of the high-resolution crystal structure (4EIY). For the calculations involving the OPLS3 force field (Table S2 and Figures S9 and S10), a newer release of the Schrodinger software was used. ${ }^{26}$ MM-GBSA calculations were performed using Prime. ${ }^{35}$

After preparation, the structures were aligned to the orientations from the Orientations of Proteins in Membranes (OPM) database. ${ }^{36}$ Structures were embedded in a membrane bilayer consisting of POPC lipids. SPC waters and counter ions were added using the system builder from Desmond. ${ }^{37}$ The OPLS2.1 force field was used. ${ }^{10 a, 38}$ Additional missing torsion parameters of the reference and crystal structure ligands were assigned using the force-field builder, which refits the missing torsion parameters to an accurate QM calculation (LMP2/ccpVTZ(-f)). Virtual sites in OPLS2.1 were used for halogens as described by Jorgensen et al. ${ }^{39}$ and for heterocycles (the DOP receptor compounds). Implementation and utilization of the force-field builder and virtual sites in OPLS3 have been recently described. ${ }^{10 \mathrm{~b}}$

Because of the relatively low resolution of the $\beta_{1} \mathrm{AR}$ structure $(2.8 \AA)$, additional water molecules were included around the (unsubstituted) reference ligand " 10 ", using the WaterMap ${ }^{40}$ algorithm. These waters were derived from the clustering of the water molecules in the binding pocket sampled during the WaterMap trajectory. ${ }^{40}$ Subsequently, all systems were relaxed using the default membrane-relaxation protocol implemented in multisim (Supporting Information). ${ }^{41}$ Because the ligands of both the $A_{2 A} R$ and DOP receptor were similar but distinct from the crystal structure ligand, the reference ligand was inserted using core-constrained docking. ${ }^{42}$ These docked poses were subjected to an additional multisim refinement of $2.5 \mathrm{~ns}$ (see Supporting Information). For both the $\beta_{1} \mathrm{AR}$ and CXCR4, a subset of ligands was selected from the original articles because of the differences in the core and size of derivatives, respectively. For simplicity, only the $S$-chiral form was considered in the final results. For one ligand, experimental results were available for both forms (e.g., 16b/16c). Calculated $\Delta G$ for all stereoisomers can be found in the Table S1.

The individual perturbations were generated using the FEP+ mapper. Each ligand is connected to at least two other ligands, and the connections represent the different perturbations performed (Figures 1-5). These maps were generated with a bias toward the reference ligand. The same protocol used here has been described before. ${ }^{9 \mathrm{a}}$ In brief, the FEP+ mapper sets up the individual perturbations and builds the system for both the solvent and complex simulations. After a short relaxation, $12 \lambda$ windows are simulated under NPT conditions at $300 \mathrm{~K}$ for 5 ns. To further enhance sampling, a "hot region" is assigned using REST. ${ }^{11 \mathrm{~d}, 43}$ Figure 4 was rendered using PyMol. ${ }^{44}$

Synthesis. All reagents used were obtained from commercial sources and all solvents were of analytical grade. Ethyl acetate (EtOAc) was redistilled before use. Demineralized water is simply referred to as $\mathrm{H}_{2} \mathrm{O} .{ }^{1} \mathrm{H}$ and ${ }^{13} \mathrm{C}$ NMR spectra were recorded at room temperature (rt) on a Bruker AC 400 $\left({ }^{1} \mathrm{H} \mathrm{NMR,} 400 \mathrm{MHz} ;{ }^{13} \mathrm{C} \mathrm{NMR}, 100 \mathrm{MHz}\right)$ spectrometer unless specified otherwise. Chemical shifts are reported in $\delta$ (ppm), and the following abbreviations are used: s, singlet; $d$, doublet; $\mathrm{dd}$, double doublet; $\mathrm{t}$, triplet; $\mathrm{q}$, quadruplet; $\mathrm{m}$, multiplet, br s, broad singlet. Coupling constants are reported in hertz and are designated as $J$. Analytical purity of the final compounds was determined by high-pressure liquid chroma- tography (HPLC) with a Phenomenex Gemini 3u C18 110A column $(50 \mathrm{~mm} \times 4.6 \mathrm{~mm}, 3 \mu \mathrm{m})$, measuring UV absorbance at $254 \mathrm{~nm}$. The sample preparation and HPLC method is, unless stated otherwise, as follows: $0.3-0.8 \mathrm{mg}$ of compound was dissolved in $1 \mathrm{~mL}$ of a 1:1:1 mixture of $\mathrm{CH}_{3} \mathrm{CN} / \mathrm{H}_{2} \mathrm{O}$ / $\mathrm{tBuOH}$ and eluted from the column within $15 \mathrm{~min}$, with a three-component system of $\mathrm{H}_{2} \mathrm{O} / \mathrm{CH}_{3} \mathrm{CN} / 1 \%$ TFA in $\mathrm{H}_{2} \mathrm{O}$, decreasing polarity of the solvent mixture in time from 80/10/ 10 to $0 / 90 / 10$. Liquid chromatography-mass spectrometry analysis was performed on a Finnigan Surveyor HPLC system with a Gemini C18 $50 \mathrm{~mm} \times 4.60 \mathrm{~mm}$ column (detection at 200-600 nm), coupled to a Finnigan Licence Controller Qualification Advantage Max mass spectrometer with electrospray ionization. The applied buffers were $\mathrm{H}_{2} \mathrm{O}, \mathrm{CH}_{3} \mathrm{CN}$, and $1.0 \%$ aq TFA. All compounds show a single peak at the designated retention time and are at least $95 \%$ pure. Thin-layer chromatography (TLC) was routinely consulted to monitor the progress of reactions, using aluminum-coated Merck silica gel F254 plates. Purification by column chromatography was achieved by use of Grace Davison Davisil silica column material (LC60A 30-200 $\mu \mathrm{m}$ ). Solutions were concentrated using a Heidolph laborota W8 2000 efficient rotary evaporation apparatus and by a high vacuum on a Binder APT line Vacuum Drying Oven.

6-Chloro-2-(cyclohexylethynyl)-9-methyl-9H-purine (5). To a solution of $4^{45}(290 \mathrm{mg}, 0.98 \mathrm{mmol})$, CuI $(18 \mathrm{mg}, 0.09$ $\mathrm{mmol}), \mathrm{Pd}\left(\mathrm{PPh}_{3}\right)_{2} \mathrm{Cl}_{2}(35 \mathrm{mg}, 0.05 \mathrm{mmol})$ in dioxane $(4 \mathrm{~mL})$ was added $\mathrm{Et}_{3} \mathrm{~N}(210 \mathrm{~mL}, 1.51 \mathrm{mmol})$ followed by cyclohexylacetylene $(140 \mathrm{~mL}, 1.07 \mathrm{mmol})$. The mixture was stirred at $\mathrm{rt}$ for $1 \mathrm{~h}$ and then filtered over Celite (cake washed with $\mathrm{CH}_{2} \mathrm{Cl}_{2}$ ). The volatiles were removed under reduced pressure and the residue was redissolved in $\mathrm{CH}_{2} \mathrm{Cl}_{2}(20 \mathrm{~mL})$, washed with $\mathrm{H}_{2} \mathrm{O}(20 \mathrm{~mL})$, and dried with $\mathrm{MgSO}_{4}$. After filtration, the volatiles were removed under reduced pressure and the residue was purified using flash chromatography on silica gel (0-2\% $\mathrm{MeOH}$ in $\left.\mathrm{CH}_{2} \mathrm{Cl}_{2}\right)$ to afford $5(263 \mathrm{mg})$. The product was reacted without further purification.

2-(Cyclohexylethynyl)-9-methyl-9H-purin-6-amine (6). To a solution of $5(260 \mathrm{mg}, 0.95 \mathrm{mmol})$ in dioxane $(70 \mathrm{~mL})$ was added $\mathrm{NH}_{3}\left(28 \%\right.$ in $\left.\mathrm{H}_{2} \mathrm{O}, 35 \mathrm{~mL}\right)$, and the mixture was heated at $70{ }^{\circ} \mathrm{C}$ for $15 \mathrm{~h}$. The volatiles were then removed under reduced pressure, and the residue was purified by flash chromatography on silica gel $\left(\mathrm{CH}_{2} \mathrm{Cl}_{2}\right.$ then $0-10 \% \mathrm{MeOH}$ in $\mathrm{CHCl}_{3} / \mathrm{EtOH}$ 99:1) to afford $6(201 \mathrm{mg})$. The product was reacted without further purification.

2-(2-Cyclohexylethyl)-9-methyl-9H-purin-6-amine (7). To a solution of $6(201 \mathrm{mg}, 0.7 \mathrm{mmol})$ in $\mathrm{EtOH}(25 \mathrm{~mL})$ was added $\mathrm{Pd} / \mathrm{C}$ (10\% on charcoal, $200 \mathrm{mg}$ ). The mixture was purged three times with $\mathrm{Ar}$ and then with $\mathrm{H}_{2}$, and the mixture was stirred at $\mathrm{rt}$ for $60 \mathrm{~h}$. It was then filtered over Celite (washed with $\mathrm{MeOH}$ ), and the volatiles were removed under reduced pressure. The residue was purified by flash chromatography on silica gel $\left(0-4 \% \mathrm{MeOH}\right.$ in $\left.\mathrm{CH}_{2} \mathrm{Cl}_{2}\right)$ to afford 7 (112 mg, 44\% over three steps). ${ }^{1} \mathrm{H}$ NMR (400 MHz, $\left.\mathrm{CDCl}_{3}\right) \delta 7.71(\mathrm{~s}, 1 \mathrm{H}), 6.02(\mathrm{br} \mathrm{s}, 2 \mathrm{H}), 3.81(\mathrm{~s}, 3 \mathrm{H}), 2.83-2.79$ $9 \mathrm{~m}, 2 \mathrm{H}), 1.81-1.77(\mathrm{~m}, 2 \mathrm{H}), 1.73-1.63(\mathrm{~m}, 5 \mathrm{H}), 1.38-1.28$ (m, $1 \mathrm{H}), 1.27-1.10(\mathrm{~m}, 3 \mathrm{H}), 1.00-0.90(\mathrm{~m}, 2 \mathrm{H}) ; \mathrm{MS} m / z[\mathrm{M}$ $+\mathrm{H}]^{+} 260.19$.

2-(2-Cyclohexylethyl)-9-methyl-8-(2H-1,2,3-triazol-2-yl)$9 H$-purin-6-amine (8). To a solution of $7(112 \mathrm{mg}, 0.43 \mathrm{mmol})$ in a $1: 1: 1$ mixture of $\mathrm{MeOH} / \mathrm{THF} /$ acetate buffer $(\mathrm{pH}=4$ (3.6 $\mathrm{mL})$ at $\left.-15{ }^{\circ} \mathrm{C}\right)$ was added $\mathrm{Br}_{2}(220 \mathrm{~mL}, 4.3 \mathrm{mmol})$. The mixture was stirred at $-15^{\circ} \mathrm{C}$ for $10 \mathrm{~min}$ and then at $\mathrm{rt}$ for 10 
min, upon which the excess of $\mathrm{Br}_{2}$ was eliminated with $\mathrm{Na}_{2} \mathrm{~S}_{2} \mathrm{O}_{5}$ (1 spatula). The $\mathrm{pH}$ was brought to $8-9$ by adding sat. aq $\mathrm{NaHCO}_{3}$, and the organic solvents were removed under reduced pressure. The residue was partitioned between $\mathrm{H}_{2} \mathrm{O}$ $(10 \mathrm{~mL})$ and $\mathrm{CH}_{2} \mathrm{Cl}_{2}(10 \mathrm{~mL})$, the layers were separated, and the aqueous layer was extracted with $\mathrm{CH}_{2} \mathrm{Cl}_{2}(2 \times 10 \mathrm{~mL})$. The combined organic layers were dried over $\mathrm{MgSO}_{4}$, filtered, and the volatiles were removed under reduced pressure. The residue was dissolved in DMF $(4.5 \mathrm{~mL})$, and $\mathrm{Cs}_{2} \mathrm{CO}_{3}(610 \mathrm{mg}, 1.73$ mmol) was added, followed by 1,2,3-triazole (100 mL, 1.73 $\mathrm{mmol}$ ). The mixture was heated at $90{ }^{\circ} \mathrm{C}$ for $15 \mathrm{~h}$, upon which the solvent was removed under reduced pressure. The residue was partitioned between $\mathrm{H}_{2} \mathrm{O}(10 \mathrm{~mL})$ and $\mathrm{CH}_{2} \mathrm{Cl}_{2}(10 \mathrm{~mL})$, the layers were separated, and the aqueous layer was extracted with $\mathrm{CH}_{2} \mathrm{Cl}_{2}(2 \times 10 \mathrm{~mL})$. The combined organic layers were dried over $\mathrm{MgSO}_{4}$, filtered, and the volatiles were removed under reduced pressure. The residue was purified by flash chromatography on silica gel $\left(0-4 \% \mathrm{MeOH}\right.$ in $\left.\mathrm{CH}_{2} \mathrm{Cl}_{2}\right)$ and then further purified by semipreparative HPLC (10-90\% $\mathrm{CH}_{3} \mathrm{CN}$ in $\mathrm{H}_{2} \mathrm{O}+0.1 \%$ TFA over $20 \mathrm{~min}$, Phenomenex Gemini C-18 5u $200 \times 10 \mathrm{~mm}, 5 \mathrm{mM}, 4 \mathrm{~mL} / \mathrm{min}$ ) to afford 8 (6.2 mg, 4.5\%). ${ }^{1} \mathrm{H}$ NMR (400 MHz, $\mathrm{CDCl}_{3}$ ) $\delta 11.25$ (br s, $1 \mathrm{H}), 8.09(\mathrm{~s}, 2 \mathrm{H}), 7.04($ br s, $1 \mathrm{H}), 4.16(\mathrm{~s}, 3 \mathrm{H}), 3.00(\mathrm{t}, J=8.0$ $\mathrm{Hz}, 2 \mathrm{H}), 1.82-1.65(\mathrm{~m}, 6 \mathrm{H}), 1.39-1.15(\mathrm{~m}, 5 \mathrm{H}), 1.03-0.97$ $(\mathrm{m}, 2 \mathrm{H}) ; \mathrm{MS} m / z[\mathrm{M}+\mathrm{H}]^{+} 327.13$; HPLC $t_{\mathrm{R}}=7.68 \mathrm{~min}$.

2-lodo-9-methyl-9H-purin-6-amine (9). To a solution of 4 (985 mg, $3.34 \mathrm{mmol})$ in $\mathrm{CH}_{3} \mathrm{CN}(13 \mathrm{~mL})$ was added $\mathrm{NH}_{3}$ ( $28 \%$ in $\mathrm{H}_{2} \mathrm{O}, 16 \mathrm{~mL}$ ). The mixture was then heated at $55^{\circ} \mathrm{C}$ for $15 \mathrm{~h}$. The volatiles were removed under reduced pressure, and the residue was precipitated by adding $\mathrm{MeOH}$. Following filtration, 9 was obtained (690 mg, 75\%, crude). ${ }^{1} \mathrm{H}$ NMR (400 $\left.\mathrm{MHz}, \mathrm{CDCl}_{3}\right) \delta 8.00(\mathrm{~s}, 1 \mathrm{H}), 7.59$ (br s, $\left.2 \mathrm{H}\right), 3.67$ (s, 3H). The product was reacted without further purification.

2-lodo-9-methyl-8-(2H-1,2,3-triazol-2-yl)-9H-purin-6amine (10). To a solution of $9(300 \mathrm{mg}, 1.1 \mathrm{mmol})$ in a mixture of DMF $(3.6 \mathrm{~mL})$ and $\mathrm{CCl}_{4}(7.2 \mathrm{~mL})$ was added $\mathrm{Br}_{2}$ $(100 \mathrm{~mL}, 1.95 \mathrm{mmol})$. The mixture was stirred at $\mathrm{rt}$ for $15 \mathrm{~h}$, upon which the excess of $\mathrm{Br}_{2}$ was removed by co-evaporation with DMF (two times $5 \mathrm{~mL}$ ) under reduced pressure. ${ }^{46}$ The residue was partitioned between $\mathrm{H}_{2} \mathrm{O}(30 \mathrm{~mL})$ and EtOAc (50 $\mathrm{mL}$ ), the layers were separated, and the aqueous layer was extracted with EtOAc $(2 \times 50 \mathrm{~mL})$. The combined organic layers were dried over $\mathrm{MgSO}_{4}$, filtered, and the volatiles were removed under reduced pressure. The residue was dissolved in DMF $(10 \mathrm{~mL})$ and $\mathrm{Cs}_{2} \mathrm{CO}_{3}(1.55 \mathrm{~g}, 4.4 \mathrm{mmol})$ was added, followed by $1,2,3$-triazole $(255 \mathrm{~mL}, 4.4 \mathrm{mmol})$. The mixture was heated at $90{ }^{\circ} \mathrm{C}$ for $15 \mathrm{~h}$, upon which the solvent was removed under reduced pressure. The residue was partitioned between $\mathrm{H}_{2} \mathrm{O}(10 \mathrm{~mL})$ and $\mathrm{CH}_{2} \mathrm{Cl}_{2}(10 \mathrm{~mL})$, the layers were separated, and the aqueous layer was extracted with $\mathrm{CH}_{2} \mathrm{Cl}_{2}(2$ $\times 10 \mathrm{~mL}$ ). The combined organic layers were dried over $\mathrm{MgSO}_{4}$, filtered, and the volatiles were removed under reduced pressure to afford $10(280 \mathrm{mg}$, crude) as a $1: 1$ mixture of isomers, which was used in the next step without further purification.

6-Amino-9-methyl-N-phenyl-8-(2H-1,2,3-triazol-2-yl)-9Hpurine-2-carboxamide (11). ${ }^{47}$ A $10 \mathrm{~mL}$ microwave tube with a stirrer bar was charged with $\mathrm{Mo}(\mathrm{CO})_{6}(174 \mathrm{mg}, 0.66 \mathrm{mmol})$ and $\mathrm{NEt}_{4} \mathrm{Cl}(109 \mathrm{mg}, 0.66 \mathrm{mmol})$. Dioxane $(1 \mathrm{~mL})$ was added and the vial was sealed. It was heated under microwave irradiation at $140{ }^{\circ} \mathrm{C}$ for $2 \mathrm{~min} .10(230 \mathrm{mg}, 0.66 \mathrm{mmol})$ was added, followed by aniline $(127 \mathrm{~mL}, 1.32 \mathrm{mmol})$, and the mixture was heated at $130{ }^{\circ} \mathrm{C}$ for $4 \mathrm{~h}$. The solvents were then removed under reduced pressure, and the residue was purified by flash chromatography on silica gel $\left(1 \% \mathrm{MeOH}\right.$ in $\mathrm{CHCl}_{3} /$ EtOH 99:1) to afford 11 (8.5 mg, 2.3\% over 3 steps). ${ }^{1} \mathrm{H}$ NMR $\left(400 \mathrm{MHz}, \mathrm{CDCl}_{3}\right) \delta 10.47(\mathrm{~s}, 1 \mathrm{H}), 8.38(\mathrm{~s}, 2 \mathrm{H}), 7.87$ (br s, $2 \mathrm{H}), 7.83(\mathrm{~d}, J=8.0 \mathrm{~Hz}, 2 \mathrm{H}), 7.39(\mathrm{t}, J=7.6 \mathrm{~Hz}, 2 \mathrm{H}), 7.13(\mathrm{~d}$, $J=7.2 \mathrm{~Hz}, 1 \mathrm{H}), 3.98(\mathrm{~s}, 3 \mathrm{H})$. MS $m / z[\mathrm{M}+\mathrm{H}]^{+}$335.93; HPLC $t_{\mathrm{R}}=6.93 \mathrm{~min}$.

$N^{2}, N^{2}, 9-T r i m e t h y l-8-(2 H-1,2,3-t r i a z o l-2-y l)-9 H$-purine-2,6diamine (13). A solution of $12^{48}(100 \mathrm{mg}, 0.4 \mathrm{mmol})$ in $\mathrm{Me}_{2} \mathrm{NH}\left(40 \%\right.$ in $\left.\mathrm{H}_{2} \mathrm{O}, 50 \mathrm{~mL}\right)$ in a sealed vessel was heated at $120{ }^{\circ} \mathrm{C}$ for $15 \mathrm{~h}$. The volatiles were removed under reduced pressure, and the residue was purified by flash chromatography on silica gel $\left(3 \% \mathrm{MeOH}\right.$ in $\left.\mathrm{CH}_{2} \mathrm{Cl}_{2}\right)$. Further recrystallization from EtOH afforded 13 (26 mg, 26\%). ${ }^{1} \mathrm{H}$ NMR (400 MHz, $\left.\mathrm{CDCl}_{3}\right) \delta 7.94(\mathrm{~s}, 2 \mathrm{H}), 5.26(\mathrm{br} \mathrm{s}, 2 \mathrm{H}), 3.89(\mathrm{~s}, 3 \mathrm{H}), 3.20(\mathrm{~s}$, $6 \mathrm{H}) ; \mathrm{MS} m / z[\mathrm{M}+\mathrm{H}]^{+} 260.00$; HPLC $t_{\mathrm{R}}=5.12 \mathrm{~min}$.

9-Methyl-9H-purine-2,6-diamine (15). ${ }^{49}$ A solution of $14^{3}$ (4.01 g, $19.75 \mathrm{mmol})$ in $\mathrm{NH}_{3}(1.5 \mathrm{M}$ in EtOH, $160 \mathrm{~mL})$ in a sealed vessel was heated at $160{ }^{\circ} \mathrm{C}$ for $\mathrm{h}$, after which full conversion was shown by TLC $\left(15 \% \mathrm{MeOH}\right.$ in $\left.\mathrm{CHCl}_{3}\right)$. The volatiles were removed under reduced pressure, and the resulting residue was purified by recrystallization from water. Product 15 was obtained as brown crystals (996 mg, 31\%). ${ }^{1} \mathrm{H}$ NMR (400 MHz, DMSO- $\left.d_{6}\right) \delta 7.65(\mathrm{~s}, 1 \mathrm{H}), 6.68$ (br s, $2 \mathrm{H}$ ), 5.83 (br, s, 2H), 3.53 (s, 3H).

9-Methyl-8-(2H-1,2,3-triazol-2-yl)-9H-purine-2,6-diamine (16). To a solution of $15(250 \mathrm{mg}, 1.52 \mathrm{mmol})$ in a mixture of DMF $(5 \mathrm{~mL})$ and $\mathrm{CCl}_{4}(10 \mathrm{~mL})$ was added $\mathrm{Br}_{2}(140 \mathrm{~mL}, 2.74$ $\mathrm{mmol}$ ). The mixture was stirred at $\mathrm{rt}$ for $15 \mathrm{~h}$, upon which the excess of $\mathrm{Br}_{2}$ was removed by co-evaporation with DMF $(2 \times 5$ $\mathrm{mL}$ ) under reduced pressure. The residue was dissolved in DMF $(20 \mathrm{~mL})$, and $\mathrm{Cs}_{2} \mathrm{CO}_{3}(1.24 \mathrm{mg}, 3.89 \mathrm{mmol})$ was added, followed by 1,2,3-triazole ( $88 \mathrm{~mL}, 15.2 \mathrm{mmol})$. The mixture was heated at $120{ }^{\circ} \mathrm{C}$ for $5 \mathrm{~h}$, upon which the solvent was removed under reduced pressure. The residue was partitioned between $\mathrm{H}_{2} \mathrm{O}(30 \mathrm{~mL})$ and hot EtOAc $(50 \mathrm{~mL})$, the layers were separated, and the aqueous layer was extracted with hot EtOAc $(5 \times 50 \mathrm{~mL})$. The combined organic layers were dried over $\mathrm{MgSO}_{4}$, filtered, and the volatiles were removed under reduced pressure. The resulting mixture was triturated with diethyl ether to afford $\mathbf{1 7}$ (289 mg, crude) as a 1:1 mixture of isomers, which was used in the next step without further purification.

$\mathrm{N}$-(6-Amino-9-methyl-8-(2H-1,2,3-triazol-2-yl)-9H-purin-2yl)benzamide (17). To a solution of $16(203 \mathrm{mg}, 0.88 \mathrm{mmol})$ in pyridine was added $\mathrm{BzCl}(500 \mathrm{~mL}, 8.78 \mathrm{mmol})$, and the mixture was stirred at $\mathrm{rt}$ for $30 \mathrm{~min}$. The reaction mixture was quenched with water $(10 \mathrm{~mL})$, and the $\mathrm{pH}$ was adjusted to $\mathrm{pH}$ $=12$ by the addition of $5 \mathrm{M} \mathrm{NaOH}(\mathrm{aq})$ solution. The organics were extracted with EtOAc $(3 \times 50 \mathrm{~mL})$ and brine $(1 \times 10$ $\mathrm{mL}$ ) and dried over $\mathrm{MgSO}_{4}$, and the volatiles were removed under reduced pressure. The residue was purified by flash chromatography on silica gel $\left(1 \% \mathrm{MeOH}\right.$ in $\mathrm{CHCl}_{3} / \mathrm{EtOH}$ 99:1) to afford 17 as a white solid (63 mg, 21\%). ${ }^{1} \mathrm{H}$ NMR $\left(400 \mathrm{MHz}, \mathrm{CDCl}_{3}\right) \delta 8.56$ (s br, $\left.1 \mathrm{H}, \mathrm{NH}\right), 8.00$ (s, 2H), 7.96$7.92(\mathrm{~m}, 2 \mathrm{H}), 7.57(\mathrm{tt}, J=7.2,1.2 \mathrm{~Hz}, 1 \mathrm{H}), 7.53-7.47(\mathrm{~m}$, $2 \mathrm{H}), 5.92$ (br s, $\left.2 \mathrm{H}, \mathrm{NH}_{2}\right), 4.05$ (s, $\left.3 \mathrm{H}\right)$; Decoupled ${ }^{13} \mathrm{C}$ NMR $\left(150.9 \mathrm{MHz}, \mathrm{CDCl}_{3}\right) \delta 165.5,155.8,153.3,151.6,142.0,137.2$, $134.8,132.2,128.8,127.5,114.3,31.4 ;{ }^{13} \mathrm{C}$ NMR without ${ }^{1} \mathrm{H}-$ decoupling $\left(150.9 \mathrm{MHz}, \mathrm{CDCl}_{3}\right) \delta 165.5$ (pseudo doublet $\mathrm{C} 2$ ), $155.8,153.3,151.6,142.0,137.2(\mathrm{dd} J=196,12 \mathrm{~Hz}), 134.8(\mathrm{t}$, $J=7.5 \mathrm{~Hz}), 132.2(\mathrm{dt}, J=162,7.5 \mathrm{~Hz}), 128.8(\mathrm{dd}, J=162,7.5$ $\mathrm{Hz}), 127.6(\mathrm{dt}, J=160,7.5 \mathrm{~Hz}), 114.3(\mathrm{t}, J=3.9 \mathrm{~Hz}, \mathrm{C} 5), 31.4$ 
$(\mathrm{q}, J=143 \mathrm{~Hz}) ;{ }^{13} \mathrm{C}$ NMR with ${ }^{1} \mathrm{H}$-decoupling $\mathrm{o} 2 \mathrm{p}=8.83 \mathrm{ppm}$ $\left(150.9 \mathrm{MHz}, \mathrm{CDCl}_{3}\right) \delta 165.5(\mathrm{~s}, \mathrm{C} 2), 155.8,153.3,151.6$, 142.0, $137.2(\mathrm{dd}, J=196,13 \mathrm{~Hz}), 134.8(\mathrm{t}, J=7.5 \mathrm{~Hz}), 132.2$ $(\mathrm{dt}, J=162,7.5 \mathrm{~Hz}), 128.8(\mathrm{dd}, J=162,7.5 \mathrm{~Hz}), 127.6(\mathrm{dt}, J=$ 160, $7.5 \mathrm{~Hz}), 114.3(\mathrm{t}, J=3.8 \mathrm{~Hz}, \mathrm{C} 5), 31.4(\mathrm{q}, J=143 \mathrm{~Hz})$; ${ }^{13} \mathrm{C}$ NMR with ${ }^{1} \mathrm{H}$-decoupling o2p $=6.06 \mathrm{ppm}(150.9 \mathrm{MHz}$, $\left.\mathrm{CDCl}_{3}\right) \delta 165.5$ (s, C2), 155.8, 153.3, 151.6, 142.0, 137.2 (dd, $J$ $=196,12 \mathrm{~Hz}), 134.8(\mathrm{t}, J=7.5 \mathrm{~Hz}), 132.2(\mathrm{dt}, J=162,7.5 \mathrm{~Hz})$, $128.8(\mathrm{dd}, J=162,7.5 \mathrm{~Hz}), 127.6(\mathrm{dt}, J=160,7.5 \mathrm{~Hz}), 114.3$ (s, C5), $31.4(\mathrm{q}, J=143 \mathrm{~Hz}) ; \mathrm{MS} m / z[\mathrm{M}+\mathrm{H}]^{+}$336.00; HPLC $t_{\mathrm{R}}=6.07 \mathrm{~min}$.

Radioligand Binding Assays. [3H]ZM241385 (45.9 Ci/ mmol) was purchased from ARC Scopus Research (Wageningen, The Netherlands). NECA was obtained from SigmaAldrich (St. Louis, MO). To determine the affinities of the proposed ligands for the $A_{2 A} R$, radioligand binding assays were performed. Affinities were determined on membranes from HEK 293 cells stably expressing this human receptor, using $[3 \mathrm{H}] \mathrm{ZM} 241385$ as the radioligand. Membranes $(25 \mu \mathrm{L})$ containing $10 \mu \mathrm{g}$ of protein were incubated in a total volume of $100 \mu \mathrm{L}$, containing $25 \mu \mathrm{L}$ of tris $-\mathrm{HCl}(\mathrm{pH} 7.4$ ) buffer, $25 \mu \mathrm{L}$ of radioligand (1.7 $\mathrm{nM}[3 \mathrm{H}] \mathrm{ZM} 241385$ plus buffer), and $25 \mu \mathrm{L}$ of the tested ligands. Incubation was done for $2 \mathrm{~h}$ at $25{ }^{\circ} \mathrm{C}$ in a shaking water bath. Nonspecific binding was determined in the presence of $10 \mathrm{mM}$ NECA. The samples were harvested after filtration over prewetted Whatman GF/B filters under reduced pressure with a Brandel harvester. Filters were washed three times with ice-cold buffer and placed in scintillation vials. Emulsifier Safe $(3.5 \mathrm{~mL})$ was added, and after $2 \mathrm{~h}$, radioactivity was counted in a TriCarb 2900TR liquid scintillation counter. Full displacement curves of the tested ligands are given in the Figures S5-S7.

\section{ASSOCIATED CONTENT}

\section{S Supporting Information}

The Supporting Information is available free of charge on the ACS Publications website at DOI: 10.1021/acsomega.6b00086.

Predicted affinities for the different chiral molecules, performance of the OPLS3 force field, predicted affinities for the 46 proposed derivatives, FEP+ maps of the different datasets, full displacement curves of the different compounds, structural difference between $4 \mathrm{EIY}$ and $3 \mathrm{PWH}$ and $\mathrm{FEP}+$ maps for both (PDF)

\section{AUTHOR INFORMATION}

\section{Corresponding Authors}

*E-mail: ijzerman@lacdr.leidenuniv.nl. Phone: +31-715274651. Fax: +31-71-5274277 (A.P.I.).

*E-mail: thijs.beuming@schrodinger.com. Phone: +1 (212) 548-2333. Fax: +1 (212) 295-5801 (T.B.).

\section{Author Contributions}

E.B.L., T.B., F.M.M., and A.N. performed the calculations. J.L., A.-F.F., and J.P.V. synthesized the compounds. H.V., and T.M.K. performed the biological experiments. E.B.L. wrote the manuscript. All authors discussed, contributed to and revised the manuscript.

\section{Notes}

The authors declare no competing financial interest.

\section{ACKNOWLEDGMENTS}

Adriaan P. IJzerman and Eelke B. Lenselink thank the Dutch Research Council (NWO) for financial support (NWO-TOP \#714.011.001).

\section{REFERENCES}

(1) Palczewski, K.; Kumasaka, T.; Hori, T.; Behnke, C. A.; Motoshima, H.; Fox, B. A.; Le Trong, I.; Teller, D. C.; Okada, T.; Stenkamp, R. E.; Yamamoto, M.; Miyano, M. Crystal structure of rhodopsin: A G protein-coupled receptor. Science 2000, 289, 739-45.

(2) Overington, J. P.; Al-Lazikani, B.; Hopkins, A. L. How many drug targets are there? Nat. Rev. Drug Discovery 2006, 5, 993-996.

(3) (a) Hollenstein, K.; Kean, J.; Bortolato, A.; Cheng, R. K.; Doré, A. S.; Jazayeri, A.; Cooke, R. M.; Weir, M.; Marshall, F. H. Structure of class B GPCR corticotropin-releasing factor receptor 1. Nature 2013, 499, 438-43. (b) Siu, F. Y.; He, M.; de Graaf, C.; Han, G. W.; Yang, D.; Zhang, Z.; Zhou, C.; Xu, Q.; Wacker, D.; Joseph, J. S.; Liu, W.; Lau, J.; Cherezov, V.; Katritch, V.; Wang, M. W.; Stevens, R. C. Structure of the human glucagon class B G-protein-coupled receptor. Nature 2013, 499, 444-9. (c) Wu, H.; Wang, C.; Gregory, K. J.; Han, G. W.; Cho, H. P.; Xia, Y.; Niswender, C. M.; Katritch, V.; Meiler, J.; Cherezov, V.; Conn, P. J.; Stevens, R. C. Structure of a class C GPCR metabotropic glutamate receptor 1 bound to an allosteric modulator. Science 2014, 344, 58-64. (d) Doré, A. S.; Okrasa, K.; Patel, J. C.; Serrano-Vega, M.; Bennett, K.; Cooke, R. M.; Errey, J. C.; Jazayeri, A.; Khan, S.; Tehan, B.; Weir, M.; Wiggin, G. R.; Marshall, F. H. Structure of class C GPCR metabotropic glutamate receptor 5 transmembrane domain. Nature 2014, 511, 557-62. (e) Jazayeri, A.; Doré, A. S.; Lamb, D.; Krishnamurthy, H.; Southall, S. M.; Baig, A. H.; Bortolato, A.; Koglin, M.; Robertson, N. J.; Errey, J. C. Extra-helical binding site of a glucagon receptor antagonist. Nature 2016, 533, 274-277.

(4) (a) Venkatakrishnan, A. J.; Deupi, X.; Lebon, G.; Tate, C. G.; Schertler, G. F.; Babu, M. M. Molecular signatures of G-proteincoupled receptors. Nature 2013, 494, 185-94. (b) Katritch, V.; Cherezov, V.; Stevens, R. C. Structure-function of the G proteincoupled receptor superfamily. Annu. Rev. Pharmacol. Toxicol. 2013, 53, 531-56.

(5) (a) Andrews, S. P.; Brown, G. A.; Christopher, J. A. Structurebased and fragment-based GPCR drug discovery. ChemMedChem 2014, 9, 256-75. (b) Beuming, T.; Lenselink, E. B.; Pala, D.; McRobb, F.; Repasky, M.; Sherman, W. Docking and Virtual Screening Strategies for GPCR Drug Discovery. Methods Mol. Biol. 2015, 1335, 251-76.

(6) Paul, S. M.; Mytelka, D. S.; Dunwiddie, C. T.; Persinger, C. C.; Munos, B. H.; Lindborg, S. R.; Schacht, A. L. How to improve R\&D productivity: the pharmaceutical industry's grand challenge. Nat. Rev. Drug Discovery 2010, 9, 203-214.

(7) Schneider, G. Virtual screening: an endless staircase? Nat. Rev. Drug Discovery 2010, 9, 273-276.

(8) Li, Y.; Han, L.; Liu, Z.; Wang, R. Comparative assessment of scoring functions on an updated benchmark: 2. Evaluation methods and general results. J. Chem. Inf. Model. 2014, 54, 1717-36.

(9) (a) Wang, L.; Wu, Y.; Deng, Y.; Kim, B.; Pierce, L.; Krilov, G.; Lupyan, D.; Robinson, S.; Dahlgren, M. K.; Greenwood, J.; Romero, D. L.; Masse, C.; Knight, J. L.; Steinbrecher, T.; Beuming, T.; Damm, W.; Harder, E.; Sherman, W.; Brewer, M.; Wester, R.; Murcko, M.; Frye, L.; Farid, R.; Lin, T.; Mobley, D. L.; Jorgensen, W. L.; Berne, B. J.; Friesner, R. A.; Abel, R. Accurate and reliable prediction of relative ligand binding potency in prospective drug discovery by way of a modern free-energy calculation protocol and force field. J. Am. Chem. Soc. 2015, 137, 2695-703. (b) Limongelli, V.; Bonomi, M.; Parrinello, M. Funnel metadynamics as accurate binding free-energy method. Proc. Natl. Acad. Sci. U.S.A. 2013, 110, 6358-6363. (c) Homeyer, N.; Stoll, F.; Hillisch, A.; Gohlke, H. Binding Free Energy Calculations for Lead Optimization: Assessment of Their Accuracy in an Industrial Drug Design Context. J. Chem. Theory Comput. 2014, 10, 3331-3344. (d) Hansen, N.; van Gunsteren, W. F. Practical Aspects of Free-Energy Calculations: A Review. J. Chem. Theory Comput. 2014, 10, 2632-47. 
(10) (a) Shivakumar, D.; Harder, E.; Damm, W.; Friesner, R. A.; Sherman, W. Improving the Prediction of Absolute Solvation Free Energies Using the Next Generation OPLS Force Field. J. Chem. Theory Comput. 2012, 8, 2553-8. (b) Harder, E.; Damm, W.; Maple, J.; Wu, C.; Reboul, M.; Xiang, J. Y.; Wang, L.; Lupyan, D.; Dahlgren, M. K.; Knight, J. L.; Kaus, J. W.; Cerutti, D. S.; Krilov, G.; Jorgensen, W. L.; Abel, R.; Friesner, R. A. OPLS3: A Force Field Providing Broad Coverage of Drug-like Small Molecules and Proteins. J. Chem. Theory Comput. 2016, 12, 281-96.

(11) (a) Woods, C. J.; Essex, J. W.; King, M. A. The development of replica-exchange-based free-energy methods. J. Phys. Chem. B 2003, 107, 13703-13710. (b) Zheng, L.; Yang, W. Practically Efficient and Robust Free Energy Calculations: Double-Integration Orthogonal Space Tempering. J. Chem. Theory Comput. 2012, 8, 810-23. (c) Jiang, W.; Roux, B. Free Energy Perturbation Hamiltonian Replica-Exchange Molecular Dynamics (FEP/H-REMD) for Absolute Ligand Binding Free Energy Calculations. J. Chem. Theory Comput. 2010, 6, 25592565. (d) Wang, L.; Friesner, R. A.; Berne, B. J. Replica exchange with solute scaling: a more efficient version of replica exchange with solute tempering (REST2). J. Phys. Chem. B 2011, 115, 9431-8.

(12) Wang, L.; Deng, Y.; Knight, J. L.; Wu, Y.; Kim, B.; Sherman, W.; Shelley, J. C.; Lin, T.; Abel, R. Modeling Local Structural Rearrangements Using FEP/REST: Application to Relative Binding Affinity Predictions of CDK2 Inhibitors. J. Chem. Theory Comput. 2013, 9, 1282-93.

(13) Bollini, M.; Domaoal, R. A.; Thakur, V. V.; Gallardo-Macias, R.; Spasov, K. A.; Anderson, K. S.; Jorgensen, W. L. ComputationallyGuided Optimization of a Docking Hit to Yield Catechol Diethers as Potent Anti-HIV Agents. J. Med. Chem. 2011, 54, 8582-8591.

(14) Jorgensen, W. L.; Bollini, M.; Thakur, V. V.; Domaoal, R. A.; Spasov, K. A.; Anderson, K. S. Efficient discovery of potent anti-HIV agents targeting the Tyr181Cys variant of HIV reverse transcriptase. J. Am. Chem. Soc. 2011, 133, 15686-96.

(15) Jorgensen, W. L. Efficient drug lead discovery and optimization. Acc. Chem. Res. 2009, 42, 724-33.

(16) (a) Hénin, J.; Maigret, B.; Tarek, M.; Escrieut, C.; Fourmy, D.; Chipot, C. Probing a model of a GPCR/ligand complex in an explicit membrane environment: the human cholecystokinin-1 receptor. Biophys. J. 2006, 90, 1232-40. (b) Boukharta, L.; Gutierrez-deTeran, H.; Aqvist, J. Computational prediction of alanine scanning and ligand binding energetics in G-protein coupled receptors. PLoS Comput. Biol. 2014, 10, No. e1003585, DOI: 10.1371/journal.pcbi.1003585. (c) Rivail, L.; Chipot, C.; Maigret, B.; Bestel, I.; Sicsic, S.; Tarek, M. Large-scale molecular dynamics of a G proteincoupled receptor, the human 5-HT 4 serotonin receptor, in a lipid bilayer. J. Mol. Struct.: THEOCHEM 2007, 817, 19-26.

(17) (a) Keränen, H.; Gutierrez-de-Teran, H.; Aqvist, J. Structural and Energetic Effects of $\mathrm{A}(2 \mathrm{~A})$ Adenosine Receptor Mutations on Agonist and Antagonist Binding. PLoS One 2014, 9, No. el08492. (b) Keränen, H.; Aqvist, J.; Gutierrez-de-Teran, H. Free energy calculations of $\mathrm{A}(2 \mathrm{~A})$ adenosine receptor mutation effects on agonist binding. Chem. Commun. (Cambridge, U. K.) 2015, 51, 3522-5.

(18) Chen, D.; Ranganathan, A.; IJzerman, A. P.; Siegal, G.; Carlsson, $\mathrm{J}$. Complementarity between in silico and biophysical screening approaches in fragment-based lead discovery against the A2A adenosine receptor. J. Chem. Inf. Model. 2013, 53, 2701-2714.

(19) Goldfeld, D. A.; Murphy, R.; Kim, B.; Wang, L.; Beuming, T.; Abel, R.; Friesner, R. A. Docking and free energy perturbation studies of ligand binding in the kappa opioid receptor. J. Phys. Chem. B 2015, $119,824-35$.

(20) Brown, S. P.; Muchmore, S. W.; Hajduk, P. J. Healthy skepticism: assessing realistic model performance. Drug Discovery Today 2009, 14, 420-7.

(21) Higgs, C.; Beuming, T.; Sherman, W. Hydration Site Thermodynamics Explain SARs for Triazolylpurines Analogues Binding to the A2A Receptor. ACS Med. Chem. Lett. 2010, 1, 160-4.

(22) Piersanti, G.; Bartoccini, F.; Lucarini, S.; Cabri, W.; Stasi, M. A.; Riccioni, T.; Borsini, F.; Tarzia, G.; Minetti, P. Synthesis and Biological Evaluation of Metabolites of 2-n-Butyl-9-methyl-8-[1, 2, 3] triazol-2-yl-
9 H-purin-6-ylamine (ST1535), A Potent Antagonist of the A2A Adenosine Receptor for the Treatment of Parkinson's Disease. J. Med. Chem. 2013, 56, 5456-5463.

(23) Thoma, G.; Streiff, M. B.; Kovarik, J.; Glickman, F.; Wagner, T.; Beerli, C.; Zerwes, H. G. Orally bioavailable isothioureas block function of the chemokine receptor CXCR4 in vitro and in vivo. J. Med. Chem. 2008, 51, 7915-20.

(24) Lenselink, E. B.; Beuming, T.; Sherman, W.; van Vlijmen, H. W.; IJzerman, A. Selecting an optimal number of binding site waters to improve virtual screening enrichments against the adenosine A2A receptor. J. Chem. Inf. Model. 2014, 54, 1737-46.

(25) Minetti, P.; Tinti, M. O.; Carminati, P.; Castorina, M.; Di Cesare, M. A.; Di Serio, S.; Gallo, G.; Ghirardi, O.; Giorgi, F.; Giorgi, L. 2-n-Butyl-9-methyl-8-[1, 2, 3] triazol-2-yl-9 H-purin-6-ylamine and Analogues as A2A Adenosine Receptor Antagonists. Design, Synthesis, and Pharmacological Characterization. J. Med. Chem. 2005, 48, 68876896.

(26) Schrödinger Release 2015-4: Desmond Molecular Dynamics System, v., D. E. Shaw Research, New York, NY, 2015. MaestroDesmond Interoperability Tools, version 4.4; Schrödinger: New York, NY, 2015.

(27) Kramer, C.; Kalliokoski, T.; Gedeck, P.; Vulpetti, A. The experimental uncertainty of heterogeneous public $\mathrm{K}(\mathrm{i})$ data. J. Med. Chem. 2012, 55, 5165-73.

(28) Bas, D. C.; Rogers, D. M.; Jensen, J. H. Very fast prediction and rationalization of $\mathrm{pKa}$ values for protein-ligand complexes. Proteins 2008, 73, 765-83.

(29) Sastry, G. M.; Adzhigirey, M.; Day, T.; Annabhimoju, R; Sherman, W. Protein and ligand preparation: parameters, protocols, and influence on virtual screening enrichments. J. Comput.-Aided Mol. Des. 2013, 27, 221-34.

(30) Doré, A. S.; Robertson, N.; Errey, J. C.; Ng, I.; Hollenstein, K.; Tehan, B.; Hurrell, E.; Bennett, K.; Congreve, M.; Magnani, F.; Tate, C. G.; Weir, M.; Marshall, F. H. Structure of the adenosine A(2A) receptor in complex with ZM241385 and the xanthines XAC and caffeine. Structure 2011, 19, 1283-93.

(31) Guo, D.; Pan, A. C.; Dror, R. O.; Mocking, T.; Liu, R.; Heitman, L. H.; Shaw, D. E.; AP, I. J. Molecular Basis of Ligand Dissociation from the Adenosine A2A Receptor. Mol. Pharmacol. 2016, 89, 485-91.

(32) Schrödinger Release 2014-3: Maestro, v.; Schrödinger, LLC: New York, NY, 2014.

(33) Berman, H. M.; Westbrook, J.; Feng, Z.; Gilliland, G.; Bhat, T. N.; Weissig, H.; Shindyalov, I. N.; Bourne, P. E. The Protein Data Bank. Nucleic Acids Res. 2000, 28, 235-242.

(34) Christopher, J. A.; Brown, J.; Doré, A. S.; Errey, J. C.; Koglin, M.; Marshall, F. H.; Myszka, D. G.; Rich, R. L.; Tate, C. G.; Tehan, B. Biophysical fragment screening of the $\beta 1$-adrenergic receptor: identification of high affinity arylpiperazine leads using structurebased drug design. J. Med. Chem. 2013, 56, 3446-3455.

(35) Schrödinger Release 2016-2: Prime, version 4.4; Schrödinger, LLC: New York, NY, 2016.

(36) Lomize, M. A.; Lomize, A. L.; Pogozheva, I. D.; Mosberg, H. I. OPM: orientations of proteins in membranes database. Bioinformatics 2006, 22, 623-5.

(37) Desmond Molecular Dynamics System, v., D. E. Shaw Research, New York, NY, 2014. Maestro-Desmond Interoperability Tools, version 3.9; Schrödinger: New York, NY, 2014.

(38) Wang, L.; Berne, B. J.; Friesner, R. A. On achieving high accuracy and reliability in the calculation of relative protein-ligand binding affinities. Proc. Natl. Acad. Sci. U.S.A. 2012, 109, 1937-1942.

(39) Jorgensen, W. L.; Schyman, P. Treatment of Halogen Bonding in the OPLS-AA Force Field; Application to Potent Anti-HIV Agents. J. Chem. Theory Comput. 2012, 8, 3895-3901.

(40) (a) Young, T.; Abel, R.; Kim, B.; Berne, B. J.; Friesner, R. A. Motifs for molecular recognition exploiting hydrophobic enclosure in protein-ligand binding. Proc. Natl. Acad. Sci. U.S.A. 2007, 104, 808-13. (b) Abel, R.; Young, T.; Farid, R.; Berne, B. J.; Friesner, R. A. Role of the active-site solvent in the thermodynamics of factor Xa ligand binding. J. Am Chem. Soc. 2008, 130, 2817-31. 
(41) Lyman, E.; Higgs, C.; Kim, B.; Lupyan, D.; Shelley, J. C.; Farid, R.; Voth, G. A. A Role for a Specific Cholesterol Interaction in Stabilizing the Apo Configuration of the Human A2A Adenosine Receptor. Structure 2009, 17, 1660-1668.

(42) (a) Friesner, R. A.; Banks, J. L.; Murphy, R. B.; Halgren, T. A.; Klicic, J. J.; Mainz, D. T.; Repasky, M. P.; Knoll, E. H.; Shelley, M.; Perry, J. K.; Shaw, D. E.; Francis, P.; Shenkin, P. S. Glide: a new approach for rapid, accurate docking and scoring. 1. Method and assessment of docking accuracy. J. Med. Chem. 2004, 47, 1739-49. (b) Halgren, T. A.; Murphy, R. B.; Friesner, R. A.; Beard, H. S.; Frye, L. L.; Pollard, W. T.; Banks, J. L. Glide: A new approach for rapid, accurate docking and scoring. 2. Enrichment factors in database screening. J. Med. Chem. 2004, 47, 1750-1759. (c) Small-Molecule Drug Discovery Suite 2014-3: Glide, v.; Schrödinger, LLC: New York, NY, 2014.

(43) (a) Liu, P.; Kim, B.; Friesner, R. A.; Berne, B. J. Replica exchange with solute tempering: a method for sampling biological systems in explicit water. Proc. Natl. Acad. Sci. U.S.A. 2005, 102, 13749-54. (b) Wang, L.; Berne, B. J.; Friesner, R. A. On achieving high accuracy and reliability in the calculation of relative protein-ligand binding affinities. Proc. Natl. Acad. Sci. U.S.A. 2012, 109, 1937-42.

(44) Liu, R.; Groenewoud, N. J.; Peeters, M. C.; Lenselink, E. B.; IJzerman, A. P. A yeast screening method to decipher the interaction between the adenosine $\mathrm{A} 2 \mathrm{~B}$ receptor and the $\mathrm{C}$-terminus of different G protein $\alpha$-subunits. Purinergic Signalling 2014, 10, 441-453.

(45) Harada, H.; Asano, O.; Hoshino, Y.; Yoshikawa, S.; Matsukura, M.; Kabasawa, Y.; Niijima, J.; Kotake, Y.; Watanabe, N.; Kawata, T. 2Alkynyl-8-aryl-9-methyladenines as novel adenosine receptor antagonists: Their synthesis and structure-activity relationships toward hepatic glucose production induced via agonism of the $\mathrm{A} 2 \mathrm{~B}$ receptor. $J$. Med. Chem. 2001, 44, 170-179.

(46) Holý, A.; Gunter, J.; Dvorakova, H.; Masojidkova, M.; Andrei, G.; Snoeck, R.; Balzarini, J.; De Clercq, E. Structure-antiviral activity relationship in the series of pyrimidine and purine $\mathrm{N}-[2-(2-$ phosphonomethoxy)ethyl] nucleotide analogues. 1. Derivatives substituted at the carbon atoms of the base. J. Med. Chem. 1999, 42, 2064-2086.

(47) Roberts, B.; Liptrot, D.; Alcaraz, L.; Luker, T.; Stocks, M. J. Molybdenum-Mediated Carbonylation of Aryl Halides with Nucleophiles Using Microwave Irradiation. Org. Lett. 2010, 12, 4280-4283.

(48) Jörg, M.; Shonberg, J.; Mak, F. S.; Miller, N. D.; Yuriev, E.; Scammells, P. J.; Capuano, B. Novel adenosine A(2A) receptor ligands: A synthetic, functional and computational investigation of selected literature adenosine $\mathrm{A}(2 \mathrm{~A})$ receptor antagonists for extending into extracellular space. Bioorg. Med. Chem. Lett. 2013, 23, 3427-3433.

(49) Kos, N. J.; Vanderplas, H. C. Deamination of 6-Amino and 6(Alkylamino)-9-Alkylpurines and Demethylation of Methylthiopurines by Sodium in Liquid-Ammonia. J. Org. Chem. 1981, 46, 5000-5003.

(50) Yuan, Y.; Zaidi, S. A.; Elbegdorj, O.; Aschenbach, L. C.; Li, G.; Stevens, D. L.; Scoggins, K. L.; Dewey, W. L.; Selley, D. E.; Zhang, Y. Design, synthesis, and biological evaluation of 14-heteroaromaticsubstituted naltrexone derivatives: pharmacological profile switch from $\mathrm{mu}$ opioid receptor selectivity to mu/kappa opioid receptor dual selectivity. J. Med. Chem. 2013, 56, 9156-69. 